da Interculturalidade à Tecnologia
Liana Miranda Chave *

\title{
A influência da arquitetura na moda brasileira e portuguesa
}

Liana Miranda Chaves ${ }^{1}$ (in memoriam) Professora do Departamento de Artes Visuais (DAV) na Universidade Federal da Paraíba (UFPB) e no Programa Mestrado Profissional em Artes (Prof-Artes-UFPB). Coordenou o Laboratório de Artes Gráficas Oswaldo Goeldi (LAG/ UFPB - 1993 a 2017). Pós-Doutora pela Escola de Comunicações e Artes (ECA/ USP). Graduada (UFPB 1983) e Doutora em Arquitetura e Urbanismo pela Universidade Federal da Bahia (2013). Mestre em Serviço Social pela UFPB (2007). Graduada em Educação Artística pela UFPB (1979). Foi Chefe do Departamento de Artes Visuais da UFPB (2007 a 2016). Faleceu em 2019.
1 Nota das editoras: a autora escreveu este texto em 2017, mas faleceu prematuramente em 2019 Foi uma trabalhadora incansável pelo ensino da Arte no Nordeste. A publicação do texto é uma homenagem que fazemos a Liana Chaves.
Resumo No presente trabalho olho a influência da arquitetura na moda brasileira e portuguesa a partir das coleções de alguns estilistas brasileiros e de um estilista português. Para tanto, faço um breve histórico da vestimenta social da moda e mostro a influência da arquitetura brasileira nas coleções de estilistas que contribuíram com a história da moda, vendo as influências das arquiteturas de Lina Bo Bardi, Oscar Niemeyer e Ruy Ohtake em algumas coleções de estilistas brasileiros. Finalmente, apresento uma coleção do estilista português Miguel Gigante com forte influência da Arquitetura Portuguesa e as tradições medievais das Aldeias Históricas de Portugal.

Palavras chave Moda, Arquitetura, Design, Brasil, Portugal. 


\section{The influence of architecture in brasilian and portuguese fashion}

Abstract AIn the present work I look at the influence of architecture in Brazilian and Portuguese fashion from the collections of some Brazilian stylists and a Portuguese stylist. To do so, I give a brief history of the social dress of fashion and show the influence of Brazilian architecture in the collections of designers who have contributed to the history of fashion, seeing the influences of the architectures of Lina Bo Bardi, Oscar Niemeyer and Ruy Ohtake in some collections of Brazilian fashion designers. Finally, I present a collection of the Portuguese stylist Miguel Gigante with strong influence of the Portuguese Architecture and medieval traditions of the Historical Villages of Portugal.

Keywords Fashion, Architecture, Design, Brazil, Portugal.

\section{La influencia de la arquitectura en la moda brasileña y portuguesa}

Resumen En este trabajo miro la influencia de la arquitectura en la moda brasileña y portuguesa de las colecciones de algunos diseñadores brasileños y un diseñador portugués. Para eso, hago una breve historia del vestir social de la moda y muestro la influencia de la arquitectura brasileña en las colecciones de diseñadores que contribuyeron a la historia de la moda, viendo las influencias de las arquitecturas de Lina Bo Bardi, Oscar Niemeyer y Ruy Ohtake en algunas colecciones de Estilistas brasileños. Finalmente, presento una colección del diseñador portugués Miguel Gigante con una fuerte influencia de la arquitectura portuguesa y las tradiciones medievales de los pueblos históricos de Portugal.

Palabras clave Moda, Arquitectura, Diseño, Brasil, Portugal. 


\section{Introdução}

A moda estudada como um fenômeno cultural tornou-se uma vertente de pesquisa que vem interessando não só os profissionais do setor de vestuário como também artistas, arquitetos, colecionadores, filósofos, sociólogos e profissionais de diversas áreas.

Muitas são as interpretações dadas em torno do papel social da moda. Ela revela diversas e variadas faces, veiculando códigos e status de quem a usa, classe social, grupo ou tribo a que pertence.

Ao longo de toda minha vida, lidar com a moda e a costura foi uma constante, visto ter sempre presentes, ao meu redor, pessoas ligadas a esse trabalho, o que me fez desde cedo perceber nuance do cotidiano ligado a esta arte e ofício. Somando-se a esses fatos, meu interesse por esse estudo foi motivado também por desenvolver já há algum tempo pesquisas sobre moda, costura, arte e técnica do vestuário.

Em 1985, comecei a lecionar na Universidade Federal da Paraíba, no então Departamento de Artes e Comunicação, atualmente Departamento de Artes Visuais. Desde 1993, coordeno o Laboratório de Artes Gráficas (LAG) onde ministro disciplinas de Gravura, Conservação e Restauro no Curso de Graduação em Artes Visuais (Licenciatura e Bacharelado) e cursos de Extensão Permanente em Estamparia em Tecido e Gravura. Tanto as disciplinas de Gravura, como os cursos de Extensão, em seus conteúdos programáticos contemplam o ensino de processos e técnicas de impressão em tecido.

Sou graduada em Educação Artística e Arquitetura e Urbanismo e ao longo da minha vida acadêmica, para complementar minha formação, participei de vários cursos rápidos, colóquios, seminários, simpósios, palestras, etc., sobre arquitetura e moda. Realizei um Curso de Especialização em Design de Moda; no Mestrado em Serviço Social, minha dissertação olhou para a moda como inclusão social e no Doutorado, minha tese versou sobre a arquitetura em locais revitalizados.

Além do que, o presente trabalho me remete às minhas origens, pois sou neta de duas avós que tinham entre tantos outros, os dons da costura e do bordado. Elas viveram dos seus ofícios, os quais amavam diversamente e às suas maneiras. E assim, fui criada com referências fortes apontando para as agulhas!

Esses ofícios sempre me surpreendem e me instigam, o que me levou a costurar e bordar "fracamente", mas com muito gosto sempre que me aventuro a elaborá-los. Tanto, que na década de 1980 criei um ateliê de costura que abrigou a "Oficina do Corpo", uma marca de roupa artesanal que fez sucesso em João Pessoa, mas que tive de fechá-lo uma década depois por motivo de força maior.

E, sempre apontando para a moda, lembro que ainda adolescente me deparei com um livro maravilhoso que me impressionou muito, não só por sua história, mas por um detalhe que marca demais a personagem principal do romance. Ela levou o marido à ruína por ser uma consumis- 
ta compulsiva de roupas. Trata-se de Emma Bovary, que Gustave Flaubert (1821-1880) retrata em Madame Bovary (1857). Aventuro-me a dizer que ele pode ter sido o escritor pioneiro que usou a moda como pano de fundo da tragédia pessoal do personagem literário.

No presente trabalho vejo a influência que a arquitetura exerce na moda e reflito a propósito de como alguns estilistas apresentam suas coleções inspirados na arquitetura. Entendo, entretanto, que apesar de existir de fato relação entre arquitetura e moda, estudar e/ou escrever sobre essas duas artes constitui um desafio porque embora haja e se presuma a relação entre ambas, ainda não há uma bibliografia específica. Dessa forma, faço um breve histórico da vestimenta social da moda, quando apresento a moda como Comunicação, Distinção, Estilo e Personalidade. Olho a influência da arquitetura em coleções de estilistas que contribuíram com a história da moda e em especial mostro a influência da arquitetura de Lina Bo Bardi, Oscar Niemeyer e Ruy Ohtake nas coleções de alguns estilistas brasileiros. Finalmente, apresento uma parte da produção do estilista português Miguel Gigante, que tem forte influência da Arquitetura Portuguesa e as tradições medievais das Aldeias Históricas de Portugal.

\section{A vestimenta social da moda}

Surgida a partir do século 14, a moda significa o conjunto de costumes, hábitos, crenças e traços comportamentais que rege a sociedade moderna como um todo. Ela busca constantemente o novo, sendo o reflexo da sua época e do que as pessoas são. Lima (2003) afirma que a palavra "moda" deriva do latim "modus", que significa maneira, modo, e que o termo surgiu na Europa Ocidental por volta dos séculos 14 e 15. Portanto, diz ela, a moda:

\footnotetext{
Como conceito que surgiu no final da Idade Média e princípio do Renascimento, foi resultado da aceleração das trocas comerciais, da prosperidade e da organização da vida das cortes do norte da Itália e da emergência da noção de indivíduo (LIMA, 2003, p. 50).
}

No final do século 19 e começo do século 20, o assunto moda passou a ser mais amplamente discutido e teorias sobre este tema ocuparam lugar ímpar nas reflexões de intelectuais e artistas que escolheram desvendar o movimento da modernidade, entendido como o novo modo de vida que se apresentava na cultura urbana da sociedade industrial.

Para artistas e intelectuais como Gustav Klimt (1862-1918), Charles Baudelaire (1821-1867), Honeré de Balzac (1799-1850), Gabriel de Tarde (1843-1904), Georg Simmel (1858-1918) e outros tantos, a moda sempre esteve em pauta como uma grande e importante personagem. Concluíram serem as ruas, os espaços de consumo e cenário de tramas sociais em que 
a aparência se apresentava como ponto de destaque. Mesmo em contextos culturais distintos - França, Alemanha e Estados Unidos - eles eram atentos ao fenômeno da moda no mundo capitalista e industrializado, analisando-a pelo prisma da distinção social. A moda, entendida como um lugar de demonstração do poder econômico das classes mais ricas, e, portanto, dominantes, foi criada também como espaço de reconstrução dos limites sociais na sociedade burguesa.

É sabido que a moda só existe se houver circulação e é por isso que é nas ruas que as "modas" se constituem, ficam conhecidas, são copiadas, se transformam, são rejeitadas e depois parecem desaparecer ou ficam esquecidas. Reaparecem mais tarde novas e repaginadas, através de releituras, como produtos do consumo capitalista.

Mesmo assim, apesar da sua importância social e econômica, a moda foi pouco estudada, pelo menos até o final do século 20. Entretanto, apesar de poucos, bons trabalhos foram publicados, a exemplo de John Flügel (1884-1955), que em 1930 publicou seu livro intitulado "The Psychology of Clothes" e a socióloga Diana Crane (1933-) o seu livro "Fashion and Its social agendas: Class, Gender and Identity in Clothing" (2000), traduzido e editado pela editora SENAC, São Paulo em 2006.

Com o final da segunda Guerra Mundial, os movimentos culturais das duas décadas seguintes além do período pós-industrial do capitalismo, colocam a questão da moda para ocupar entre os pesquisadores um lugar de destaque.

No Brasil, Gilda de Melo e Sousa (1919-2005) publica em 1952, na revista do Museu Paulista, sua tese de doutorado em Ciências Sociais, intitulada "O espírito das roupas: a moda do século XIX".

Em Paris, Roland Barthes (1915-1980) escreve em 1967, "O Sistema da Moda", reiniciando pelos intelectuais os estudos voltados para esse campo. Ali, ele faz uma abordagem semiológica sobre a moda, dentro da tradição ensaística em voga na primeira metade do século 20 . Outra publicação importante no campo da sociologia da cultura foi "O costureiro e sua Grife" (1975), de Pierre Bourdieu (1930-2002) e Yvette Delsaut. Naquele artigo, eles analisam a teoria da reprodução das classes e dos gostos sociais, quando a moda é pensada a partir da distinção social.

Entre o final da década de 1970 e começo da década de 1980, acentuou-se a globalização e o mundo da moda foi ficando cada vez mais complexo e aumentando, evidentemente, cada vez mais sua importância social. O que era privilégio das elites no século 19, no plano da construção de identidades e estilos de vida, passou também a ser dos indivíduos de outras camadas sociais. O novo olhar que a moda despertou em todos, começou a gerar uma onda de pesquisas empíricas e históricas, propiciando o aparecimento de diversos trabalhos acadêmicos nesta área, uma vez que começaram a abertura de cursos de moda tanto nas universidades como em escolas particulares, cursos técnicos, etc. 
Alguns trabalhos como os de Daniel Roche (1935-) que escreve sobre a cultura das aparências, os de Phillippe Perrot (1967-2015) que analisa a indumentária burguesa do século 19, os de Elizabeth Wilson (1921-2015) na Inglaterra e os de Gilles Lipovetsky (1944-) na França, que publicam em 1987 ensaios críticos sobre a evolução da moda nos séculos 19 e 20, são também considerados clássicos. Por caminhos diversos transferiram o foco da discussão teórica da distinção social para a questão dos estilos de vida. Estes historiadores e sociólogos iniciaram um movimento que tinha como objetivo projetar a história da moda na modernidade.

Entre os anos de 1990 e 2000, tanto na Inglaterra, Itália e França como nos Estados Unidos, foram criados grandes e importantes polos de pesquisa em moda. Finalmente, no Brasil, o estudo referente à moda deixou de ser visto como uma futilidade, uma coisa exótica atrelada ao "caráter frívolo". Atualmente, em todo o mundo, a pesquisa em moda é considerada bastante importante, e assim, ela está ganhando espaço tanto no âmbito acadêmico como na esfera cultural. Ao ganhar espaço são criados inúmeros cursos referentes ao assunto nos níveis técnico, de graduação e pós- graduação nas universidades e escolas privadas, cursos esses direcionados a moda, uma vez que a procura por estudos nessa área está crescendo cada vez mais.

\section{Moda é Comunicação, Distinção, Estilo e Personalidade}

A moda é um fenômeno cultural e a roupa um recurso tecnológico que representa a condição social de quem a usa, traduzindo a personalidade do indivíduo ou o desejo de ser de cada um, nos mais diversos períodos da civilização. Devido à sua versatilidade, a moda fortemente se mostra como um meio de comunicação. Lipovetsky (1989) diz que a roupa é uma das mais importantes formas de comunicação visual, onde as pessoas, intencionalmente ou não, dialogam entre si revelando seu eu. Dessa maneira, a moda passa a ser um dispositivo social presente na interação com o mundo.

Alguns sociólogos dizem que o vestuário fala, pois existem linguagens, códigos vestimentares. Para Umberto Eco (1932-2016) no seu artigo "O hábito fala pelo monge" (1989, p.12), "a roupa é comunicação... e se a comunicação se estende em todos os níveis, não há porque estranhar que exista uma ciência da moda como comunicação e da roupa como linguagem articulada". Ele diz ainda que "os códigos do vestuário existem, embora muitas vezes sejam fracos, ou seja, mudam com rapidez, e são frequentemente reconstruídos no momento, na situação dada" (ECO, 1989, p.18).

Em seu livro "Moda e Comunicação" (2003), Malcolm Bernard diz que "uma peça de roupa não é moda até que alguém a use para indicar sua posição social real ou ideal". Diz ainda ser a moda uma comunicação e a indumentária se apresentando como uma figura de comunicação não verbal. Dessa forma, para ele, as modas e indumentárias são entendidas como meios para dar sentido às pessoas, as coisas e ao mundo. 
Em "Os meios de comunicação como extensão do homem" (1964) e "Guerra e paz na aldeia global" (1971), Marshall McLuhan (1911-1980) afirma que a vestimenta é realmente o prolongamento do corpo e dos próprios tecidos e que a roupa é a extensão da pele, um meio de definição social do ser e um espaço de comunicação. Para tanto, e não sem razão, que no final da década de 1990 surge no mercado de trabalho um profissional denominado consultor de imagem que cuida do visual do cliente construindo sua imagem. Entretanto, somente há aproximadamente vinte anos surgiu o termo personal stylist.

Para Quentin Bell (1910-1996) o vestuário é o prolongamento do corpo e as "nossas vestimentas são tão parte de nós mesmos que não podemos jamais ser indiferentes a seu estado: é como se o tecido prolongasse naturalmente o corpo, até mesmo a alma" e assim pode-se avaliar o valor que ele dedica à indumentária. Sendo quase igual a dizer que "o sentimento de estar perfeitamente elegante nos traz uma paz interior que a religião procura em vão nos dar" (BELL, 1992, p. 18).

Simmel (1988) analisa o elemento da imitação de modo duo: a distinção e a imitação. Assim, essencialmente no campo da moda vestuário, tanto o homem necessita e tem vontade de imitar o outro como na mesma medida ele quer ser diferente. Assim, ele analisa a moda, afirmando que a distinção das classes mais abastadas passa pelo lançamento da novidade, sendo copiado pelas classes menos favorecidas. Num ciclo contínuo, ela é instigada a inventar outra novidade, que mais uma vez será imitada, e assim por diante, sendo o fenômeno da moda a própria "bola de neve".

Assim, Michell Maffesoli (1944-) informa que "a moda pode ser considerada como um bom exemplo da imitação/identificação no qual a periferia está por todos os lados, e o centro em parte alguma" (MAFFESOLI, 1998, p. 281).

Pierre Bourdieu (1930-2002) discute as lutas simbólicas observando a distinção, adquirida pela soma das experiências acumuladas. Elas são incorporadas, enquanto a distinção divulgada é totalmente artificial. Daí o excesso e a necessidade de consumo (BOURDIEU, 1979). Esta discussão também é reforçada por Jean Baudrillard (1929-2007) quando diz que "a moda não reflete uma necessidade natural de troca: o prazer de mudar de vestidos, de objetos, vem para sancionar psicologicamente coações de outra ordem, coações de diferenciação social e de prestígio" (BAUDRILLARD, apud CROCI e VITALE, 2000, p. 60). E Bourdieu (1979) diz que a moda e os acessórios fazem a imagem de um ser almejado e ansiosamente desejado.

Edward Sapir (1884-1939) afirma em 1967 que a moda é uma espécie de símbolo da distinção social e que a renovação do guarda-roupa produz satisfação, induzindo em quem o renova o desejo de alcançar importância e fama.

É, portanto, com esse olhar que se privilegiou, por muito tempo, a inquietação com a distinção social como componente que explica a roda viva em que vive a moda, sendo inclusive a explicação para os rápidos períodos de mutação do seu universo. 
Assim, a vestimenta simboliza uma determinada cultura. Por isso, em "Cultura e Razão Prática" (1979), Marshal Sahlins (1930-) observa que a vestimenta - esse objeto de desejo para muitos - nada mais é do que um mundo figurado materializado, e que no código da moda, a roupa espelha categorias entre as classes sociais, grupos etários, além de distinguir a feminilidade e masculinidade da maneira como a sociedade se apresenta. Por meio do vestuário se distingue as roupas vestidas no dia a dia, para o dia e para a noite, para as festas e passeios, nos feriados e dias festivos, no centro e nos bairros, no campo e na cidade, etc. E, que a aparência para as classes sociais das sociedades ocidentais tem importância fundamental na grandeza simbólica da vestimenta.

Estilo, uma palavra originada do italiano stiletto, e mais tarde, no século 18 do inglês style, que significa "a maneira particular como cada pessoa exprime suas emoções, pensamentos e sentimentos". Na realidade é uma forma de expressão com características originais, como se fosse uma assinatura. Pode-se associar a criação de uma marca pessoal, um modo singular do indivíduo ou sua aparência que é ímpar, uma estética original ou as características próprias do indivíduo expressando uma época. Um exemplo bem conhecido e marcante é o "estilo Chanel", referência à estilista-costureira Gabrielle Bonheur Chanel (1883-1971), a Coco Chanel.

Em "Cenas Juvenis" (1994), Helena Abramo define manifestações tipo: punks e darks como estilos espetaculares, que têm como objetivo primeiro o de contestar valores e crenças dominantes e pré-estabelecidos na sociedade, sendo por isso que tão rapidamente os adolescentes deixam de gostar de certo tipo de roupa, substituindo facilmente, se isso fizer parte de um "estar-junto", partilhar determinados gostos e hábitos, só para estar igual a "moçada", a "galera".

Simmel, em "A Coqueteria e outros ensaios" (1998), no texto "O problema do estilo" discute entre outras coisas a semelhança entre o estilo e a língua. Diz que o estilo assim como a língua tem seus sons, suas flexões e sínteses próprias apesar de vida própria.

Assim, o estilo de uma pessoa que consome um determinado acessório ou vestuário que porventura "esteja na moda" é conduzido à ideia de uma identidade que pode ter função específica e pontual bem como descartável e efêmera. Entretanto, há o desejo de distinguir-se do outro, de ser diferente e chamar a atenção dos demais, ainda que temporariamente.

Nesse momento cabe também uma discussão: por um lado, imitar, querer estar igual aos pares, e estar na moda. Por outro lado, ser diferente e particularmente singular.

O estilo de alguém pode chamar a atenção por ser diferente, por ser ímpar. O mesmo pode passar despercebido em outro local e não visto como original, uma vez que tudo é só uma questão de local e contexto da observação do observado e do observador.

Alguns autores acreditam que a vestimenta é quem faz a personalidade. E assim como a linguagem, a roupa é lida e decodificada, passando a identificar o indivíduo como se fosse sua carteira de identidade. 
Como já disse anteriormente, para Gilles Lipovetsky (1989) “a moda não se encerra no vestir, mas está interligada ao bem estar", enquanto que para Roland Barthes (1967) "se vestir é um ato de significação e, portanto, um ato profundamente social instalado no coração da dialética das sociedades". Sendo assim, entendo que a cobertura corporal é puramente cultural. É pertinente observar que ao se vestir, o homem exerce um ato significante que é trajar uma roupa sendo quase que indiscutivelmente uma ação que vai além de uma proteção, ou pudor, ou até enfeite. $O$ traje pode se tornar costume e socialização, sendo inerente a todo ser humano, uma vez que como argumenta Barthes (1967) "diz respeito a todo corpo humano, (...) as relações do homem com seu corpo e este com a sociedade".

Portanto, a moda está na combinação das peças que o homem seleciona e usa, generalizando o sistema do vestir, expondo ou abrindo para que elas se tornem algo compartilhado coletivamente, reproduzidas em larga escala. $\mathrm{O}$ vestuário significa e se decide como uma escolha pessoal. A relação entre a sociedade e o homem vestido, indicando o código do vestir, pode ser avaliada a partir das transformações maiores que definem a roupagem e também de análises entre as chances de propagação e recebimento pela sociedade.

A moda no século 19 evidencia a ascensão da obscuridade e do sujeito, procura a elevação via a exterioridade e a dúvida com o ideal de igualdade e acomodação. Entretanto, a massificação e a singularidade são movimentos que ainda impulsionam as preferências de trajes. Não é de se estranhar que de algum modo é esta interseção entre corpo e sociedade que aguça a atenção de estudiosos pelo se vestir.

É na segunda metade do século 20 que Jean-Paul Charles Aymard Sartre (1905-1980) diz que a roupa consente ao usuário assumir sua liberdade, mesmo se o que ele eleger já tenha sido selecionado antes, por outros. Balzac, Baudelaire, Proust, entre outros, diziam que "a vestimenta é como um viés que une todas as criaturas". A vestimenta desperta interesse por sua relação com a personalidade que por sua vez faz a moda, que faz a vestimenta e novamente esta, faz a personalidade.

Em “The Psychology of Clothes", Flügel (1950) escreve na perspectiva psicanalista, utilizando símbolos freudianos. Descreve o traje como personalidade inconsciente, analisa as escolhas e comportamentos através da vestimenta fixa e a que reflete o tempo da moda. A vestimenta fixa é a que ligada ao tempo, revela uma permanência. Já a outra ligada à dinâmica da moda, tem sua expansão e transformação rápida além das inovações dos indivíduos adeptos à massificação através das informações midiáticas. Ele diz que a roupa como mensagem que comunica, quebra de vez o eterno triângulo proteção, pudor e adorno.

Toby Fischer-Mirkin em "O código de vestir" (2001) diz que a escolha de um traje não é um ato mecânico. 0 escolher é repleto de intenções ocultas e significados só acessíveis aos entendidos, e que o "escolher" muitas vezes ajuda a pessoa a entender o que sua roupa está informando aos outros. 
Portanto, a aparência indica sempre a identidade da pessoa, sexo, profissão, etc. Voltando aos anos 1700, parisienses e londrinos cuidavam para que o ditado "a primeira impressão é a que fica", fosse o que realmente contasse. Não era à toa que passeavam pelas ruas e adentravam nos cafés, com indumentárias que diziam seus status sociais. Na época, a sociedade era delimitada e a indústria da moda tinha o papel fundamental naquele contexto. Tratava-se das famosas "leis suntuárias" que, além de ditar os trajes que eram apropriados à determinada classe social, informava como era a pessoa, o que fazia, etc., fazendo com que a aparência corporal se tornasse uma ficha identitária.

Atualmente, a moda é bastante democrática. Cada indivíduo lança mão do seu estilo e é a partir dele que a identidade se formata. Nesta concepção, muitas vezes é possível identificar a personalidade e interesses através do que se veste. Para garantir a sobrevivência social, é comum ser encontradas "personalidades mutantes". E a moda possibilita essa mutação, quando ela se mostra como agente modificador. Assim sendo, a moda pode funcionar como uma "fantasia", cabendo ao indivíduo escolher o que irá vestir, de que forma e como pode se mostrar.

\section{A influência da Arquitetura na Moda}

Moda e Arquitetura são áreas criativas que tratam de estrutura, proporção e equilíbrio, princípios que norteiam o traçado propositivo, em suas distintas escalas e suportes. Essas artes se aproximam uma vez que vestir e habitar são duas necessidades básicas análogas, que residem na interação entre o eu e o não-eu, entre as pessoas e o meio físico e social.

Voltando ao artigo "O hábito fala pelo monge", Eco (1989) conta que, atualmente a função da roupa é de cobrir e proteger o indivíduo, do calor ou do frio, não passa de cinquenta por cento do conjunto de um vestuário e que o resto é uma opção ideológica, uma mensagem, uma comunicação. 0 mesmo acontece na arquitetura quando o edifício cede sua função no projeto para ser visto e lido como o discurso que o arquiteto ou quem o encomendou quer passar.

Entendendo que o corpo é o elemento de conexão entre moda e arquitetura, uma vez que componentes - estrutura, volume, transparência, material, etc. - se fazem presentes tanto na arquitetura como também são encontrados na indumentária, não é de se estranhar que estilistas explorem o universo arquitetônico em suas criações e arquitetos inspirem-se na moda para conceber novos conceitos em projetos arquitetônicos.

Em "Registros de uma vivência" (1995), o arquiteto e urbanista Lúcio Costa (1902-1998) diz que o princípio básico da arquitetura é a construção. E que arquitetura não deveria ser o simples construir desordenado, mas o construir de forma "ordenada e organizada no espaço para determinada finalidade e visando a determinada intenção" (COSTA, 1995, p. 246). 
Para o arquiteto Aldo Rossi (1931-1997), em "A arquitetura da cidade" (2001), a arquitetura é compreendida como um ambiente construído onde acontecem as relações humanas. Assim, a importância da arquitetura deve-se a essa capacidade intrínseca de projetar os ambientes que juntos formarão a cidade onde:

O elemento coletivo e o elemento privado, sociedade e indivíduo, contrapõem-se e confundem-se na cidade, que é feita de inúmeros pequenos seres que procuram uma acomodação e, junto com ela formando um todo com ela, um pequeno ambiente mais adequado ao ambiente geral (ROSSI, 1995 p. 3).

Em uma palestra na Expo Revestir/2010, o arquiteto italiano Francesco Lucchese, falou que "a moda e a arquitetura nos protegem, nos dão abrigo e expressam nossa identidade pessoal, política, religiosa e cultural."

Tanto a arquitetura - edifício - como a moda - vestimenta - possuem a função de proteger o homem, bem como nutrem a ideia de abrigo, além do que essas artes sempre dialogaram, expressando o contexto social de um período, apesar de se apresentarem em diferentes linguagens. Sendo a roupa essencialmente criada para cobrir o corpo do indivíduo e a casa para abrigá-lo em proporções maiores.

Linhas retas ou curvas, cores e texturas são palavras difíceis de definir se o assunto trata da moda ou da arquitetura. Na realidade, as duas artes andam juntas, mais juntas do que se imagina, uma vez que tanto uma como outra proclamam tendências e acontecimentos de determinadas épocas com linguagens diferentes, além de expressarem e materializarem ideologias. Dessa forma, tanto a roupa, como a casa e a cidade, tem significações psicológicas de caráter especialmente protetor, de agasalho, de abrigo. Sendo por isso que muitas vezes a moda, nas suas releituras se utiliza das estruturas arquitetônicas para se materializar em peças do vestuário. E, da mesma maneira que um edifício pode influenciar um modelo de traje, ou uma coleção, uma indumentária pode igualmente influenciar um projeto arquitetônico.

O estilista espanhol Cristobal Balenciaga (1895-1972) foi considerado o "arquiteto da moda", pois soube fazer da arquitetura uma fonte de inspiração para propor roupas em perfeita sintonia com as proporções do corpo feminino. François Baudot (1950-2010) afirmou que:

Balenciaga possuía a maestria absoluta do corte, dominando uma ciência verdadeiramente tecnológica da indumentária e pesquisando incansavelmente a harmonia perfeita entre silhueta, proporções e postura, a arte de Balenciaga se aproxima muito da arquitetura (BAUDOT, 2000 p. 154-158). 
Desde o início do século 20 tanto a arquitetura como a moda tiveram a influência do estilo Art Noveau - linhas curvas, formas orgânicas e motivos naturais. Segundo Braga (2007), o corpo feminino tornou-se um verdadeiro repositório de linhas curvas, onde a cintura nunca tinha sido tão fina como naquele momento.

As figuras 01 e 02 demonstram a influência da arquitetura de Gaudí nos modelos da Belle Époque, evidenciando a fonte de inspiração desses modelos expostos abaixo.
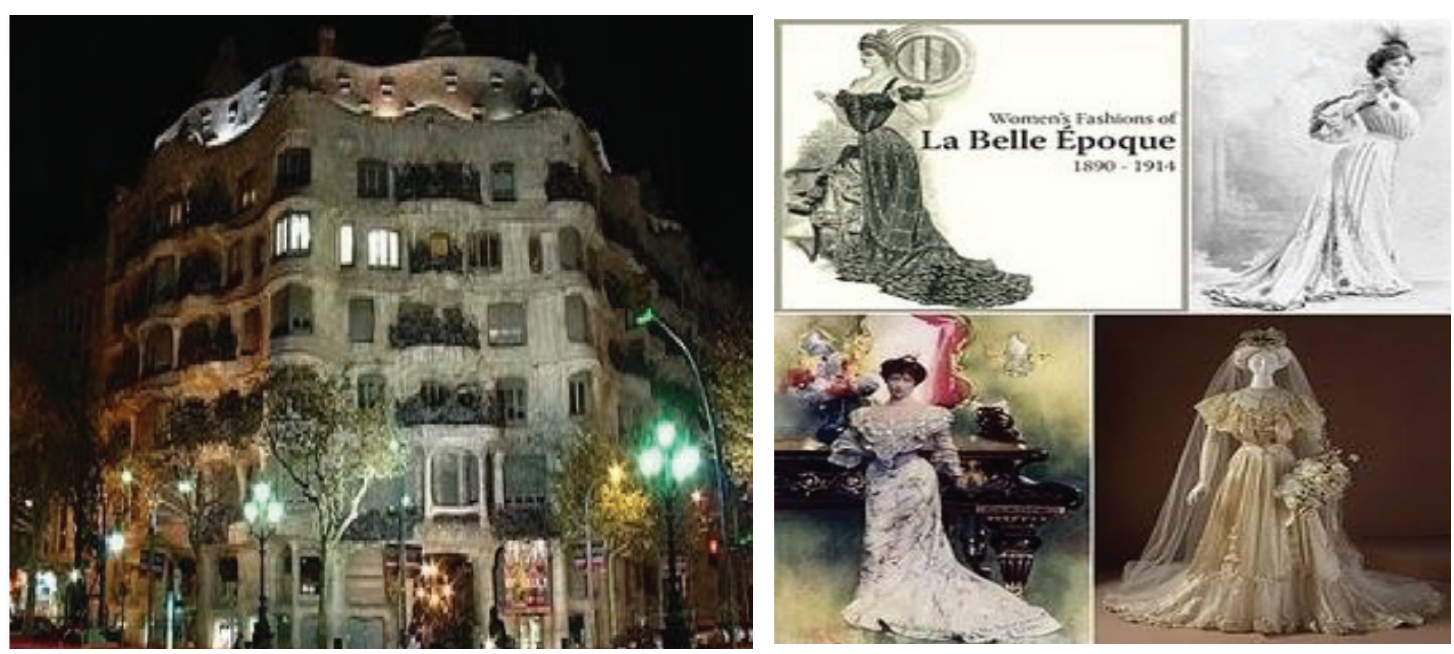

Fig 1. Casa Milà de Antôni Gaudí - Espanha, 1907

Fig 2. Modelos inspirados na Casa Milà de Antôni Gaudí

Fonte: Chaves, 2017

O engenheiro Yopanan Rebello, em entrevista à Revista AU ( $n^{\circ}$ 133, abril/2005), afirma que "a roupa pode ser vista em primeira instância, como o abrigo imediato, mais próximo da pele humana do que qualquer outro elemento que a arquitetura possa conceber". E continua dizendo que "ela é uma espécie de arquitetura primeira, abrigo que se descola da pele do homem e se projeta ampliando sua ocupação".

A Coleção de 2014 "A costura do invisível" do estilista Jum Nakao (1966-) em que a saia, vista abaixo, devido a sua solução estrutural remete a Coberta do Ginásio e da Piscina da Arena Olímpica em Tóquio, projeto do arquiteto japonês KenzoTange (1913-2005). Nota-se que a saia e a coberta apresentam conceitos estruturais semelhantes (Figuras 03 e 04).

Coco Chanel dizia que "Moda é arquitetura: sendo uma questão de proporção". Fazendo clara referência dos seus tailleurs com a Ville Savoye de Le Corbusier (1887-1965), vistos abaixo nas Figuras 05 e 06.

Nos séculos passados, diversos movimentos estreitaram ainda mais a parceria entre esses dois mundos. Não é difícil relacionar as linhas de Chanel com a arquitetura de Le Corbusier e da Bauhaus. 
Figs 3 e 4. Coberta do Ginásio e da Piscina da Arena Olímpica de Tóquio, projeto de KenzoTange (1968) e Saia de Jum Nakao (2004)

Fonte: Chaves, 2017

Figs 5 e 6. Tailleur Chanel (década de 20) e Ville Savoye de Le Corbusier, 1928 Fonte: Chaves, 2017
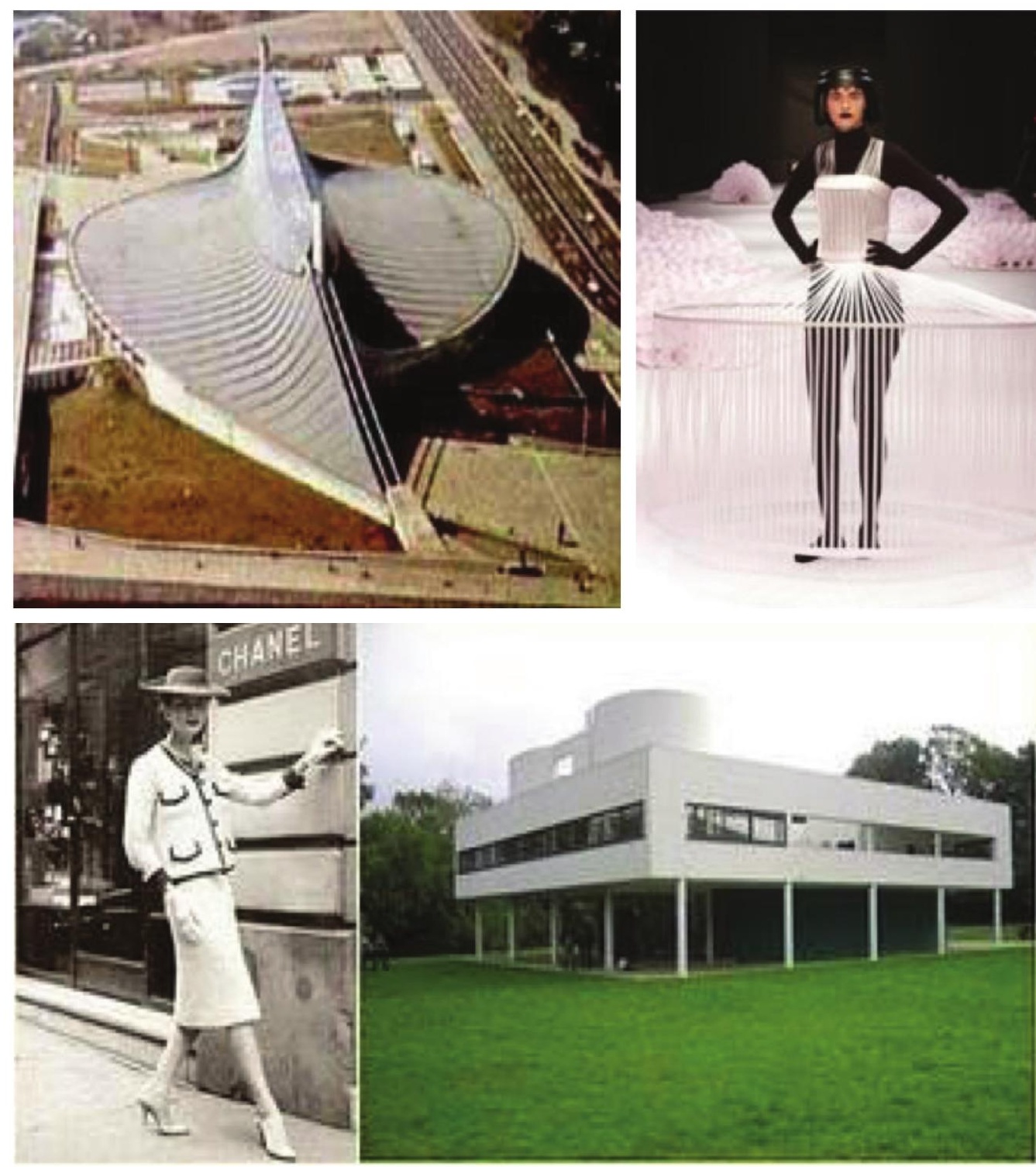

Na palestra citada acima, Lucchese assevera que "os materiais são como instrumentos da arquitetura que, assim como a moda, criam a forma, a escultura, etc.". As figuras 07, 08, 09, 10, 11, 12, 13 e 14 demonstram a influência da arquitetura na moda. 
Figs 7 e 8 . Yoshiki Hishinuma e o edifício Tod's (Toyo Ito), Tokyo, 2004 Fonte: Chaves, 2017

Figs 9 e 10. Coleção Paco Rabanne e o edifício Prada em Tóquio. Projeto de Tadao Ando e Captone, 2009 Fonte: Chaves, 2017

Figs 11 e 12. Armani e o Palácio de Diamante Ferrara - Itália, 1493 Fonte: Chaves, 2017

Figs 13 e 14. Produção do Atelier Manferdini e Edifício Mikimoto. Projeto de Toyo Ito - Tóquio, 2005

Fonte: Chaves, 2017
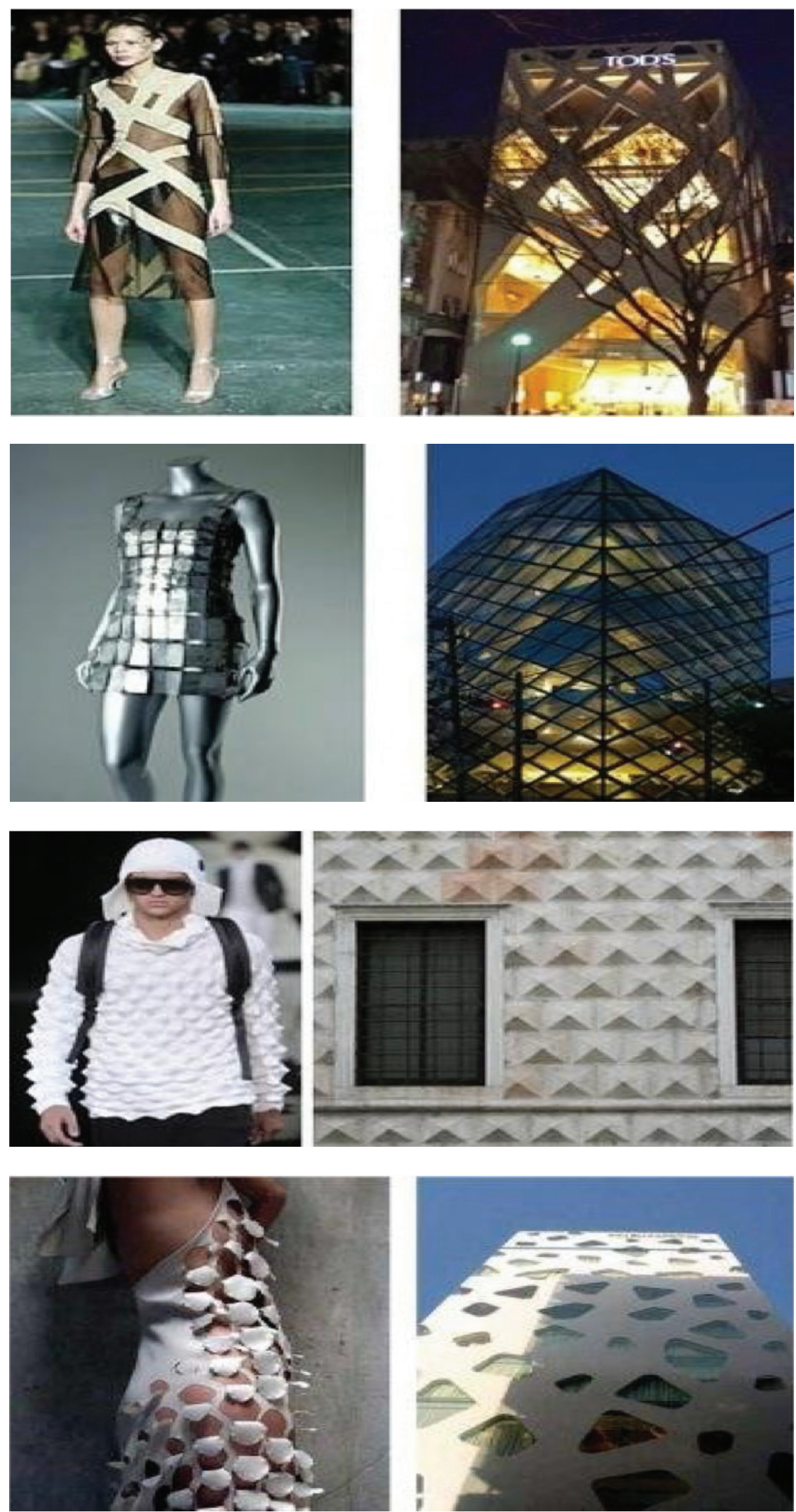

DATJournal v.5 n.22020 
Muitos afirmam que a arquitetura é a senha para entender a silhueta moderna. A arquitetura alimenta a poética do abrigo - estruturas, volumes, cheios e vazios, luz e sombra, transparências, materiais, cortes e recortes. Na moda, essa escala se materializa no corpo, que muitas vezes olha para o fazer arquitetônico como fonte de inspiração.

Não sem motivo, em uma entrevista, o estilista Reinaldo Lourenço, disse que "A moda é a arquitetura do corpo. É muito importante para a moda pensar com a cabeça de arquiteto. (...) Sempre olhei para a arquitetura. Olhei já para Art Nouveau, Art Deco, Brasília... não tem como viver fazendo moda sem olhar para a arquitetura."

Sem dúvida, uma das maiores obras da arquitetura da virada do século 20 foi o projeto do arquiteto Frank Gehry para o museu Guggenheim, em Bilbao, na Espanha (1997). Nascida de um desconstrutivismo orgânico, provavelmente inspirou uma das criações do estilista John Galliano (2003), Figuras 15 e 16.
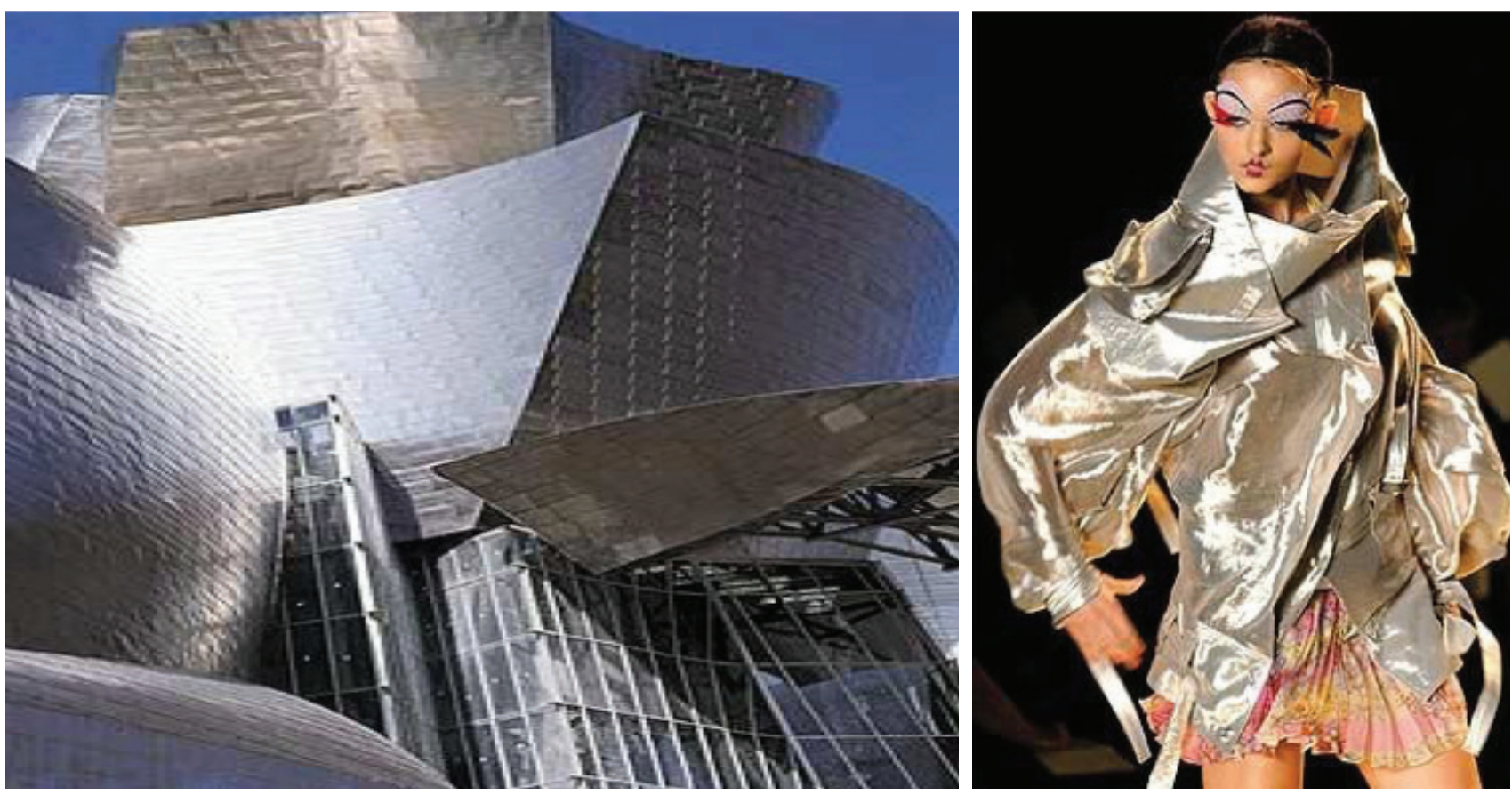

Figs 15 e 16. Museu Guggenheim - Espanha - Projeto de Frank Gehry, 1997. Coleção John Galliano, 2003 Fonte: Chaves, 2017

$\mathrm{O}$ arquiteto Roberto Loeb, autor do projeto de uma fábrica da Natura (2001), sugere que o relacionamento entre arquitetura e moda se situa preponderantemente no campo das atitudes e dos conceitos, afirmando que:

Não penso que haja uma regra fixa ou padrão, depende da sensibilidade e individualidade do designer... Pode-se ler a arquitetura com um olhar de integração ou contraposição. Valem a individualidade e a potência do criador, arquiteto ou designer, valem a inovação e a celebração da vida (CHAVES, 2017). 
Se por um lado, alguns arquitetos acreditam que a arquitetura é uma arte maior e mais importante que a moda, por outro se sabe que a importância da moda se encontra no fato de que ela dialoga mais rápido e democraticamente com o público.

\section{Lina Bo Bardi, Oscar Niemeyer e Ruy Ohtake influenciam estilistas}

A influência da arquitetura brasileira na moda pode ser observada nas passarelas com algumas coleções de estilistas brasileiros. Uma das obras mais emblemáticas da arquiteta italiana naturalizada brasileira Lina Bo Bardi (1914-1992) foi usada como a grande inspiração para as releituras da estilista Danielle Jansen, da grife carioca Maria Bonita, para a coleção apresentada no São Paulo Fashion Week - outono/inverno 2010. O desfile aconteceu no Sesc Pompéia, uma obra restaurada, revitalizada e requalificada assinada por Lina.

A escolha do local foi extremamente feliz, pois foi possível observar in loco em que aspectos a arquitetura foi traduzida nas roupas. Os blocos de concreto aparente, as telas que preenchem as janelas sinuosas do prédio estavam ali, redefinidas em forma de tecido. Até as cores, usadas sempre comedidamente por Lina, foram aplicadas em soluções criativas, como no penteado de estilo geométrico das modelos, que ganharam uma risca colorida do hair stylist Celso Kamura.

Danielle informa o porquê da influência de Lina Bo Bardi em sua coleção. "Lina é tão complexa, são tantos ângulos para se olhar, que é impossível dizer por qual aspecto me apaixonei mais", declara a estilista. Ela destaca o diálogo de Lina entre o moderno e o artesanal, a capacidade de transformar o feio em beleza espontânea e sua paixão pelo Brasil.

Fig 17. A trama do tecido do vestido é idêntica à tela das janelas do Sesc Pompéia. Projeto de restauração de Lina Bo Bardi, 1982 | Fonte: Chaves, 2017

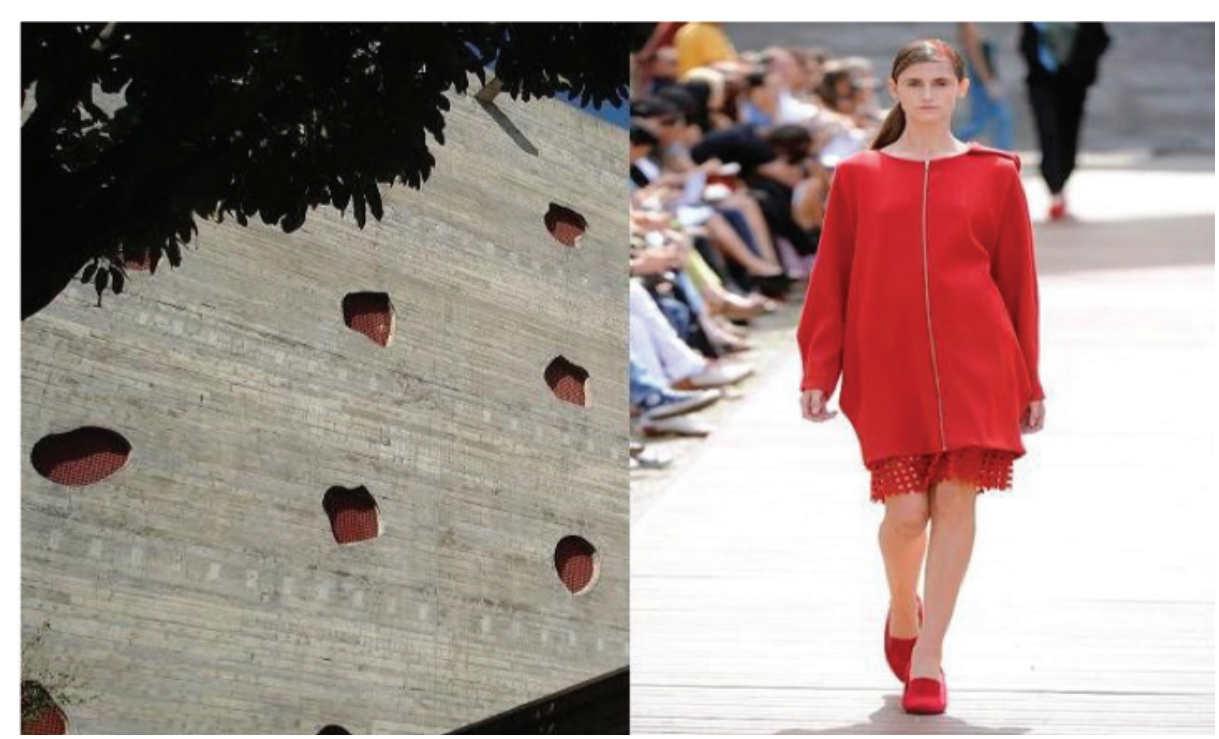


Fig 18. Vestido com retângulos de tecido cinza remetem aos blocos de concreto aparente do projeto de restauração Lina Bo Bardi, 1982

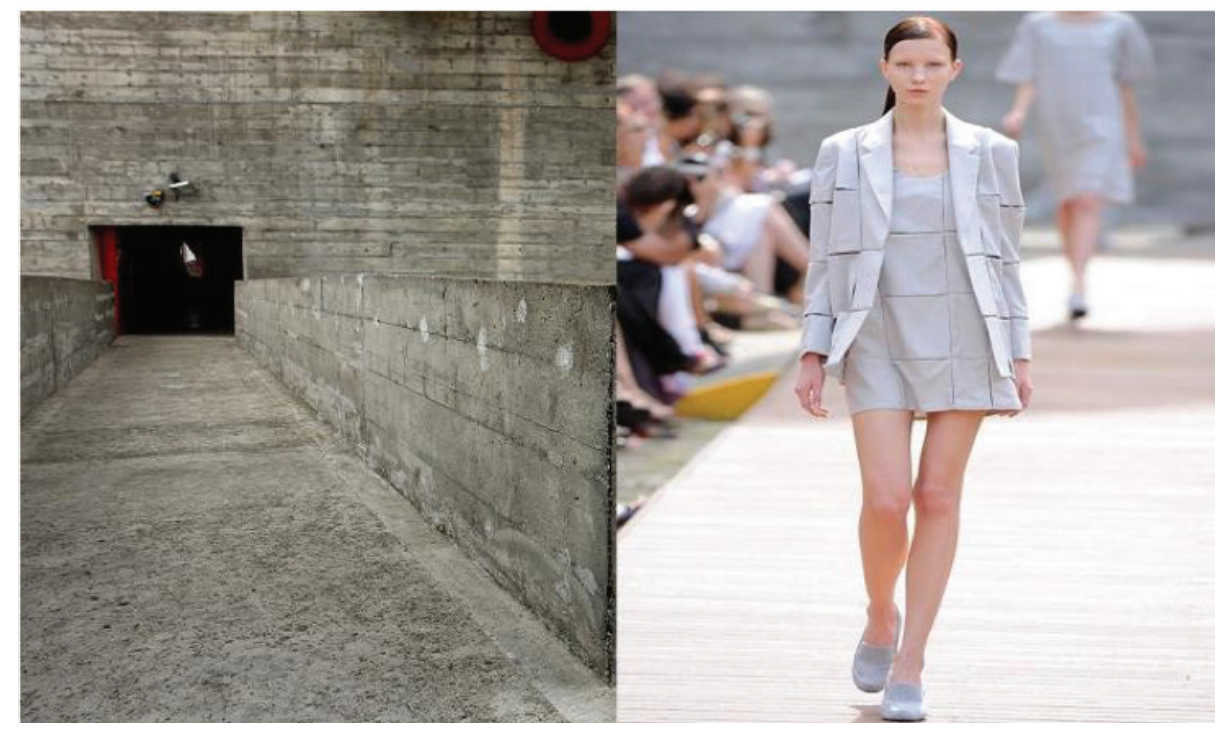

Expoente brasileiro da arquitetura moderna e mestre das curvas inspiradas na mulher - e do concreto armado, sua obra tem inspirado muitos e em vários campos. Em Paris na sexta-feira, dia 05 de março de 2010, o estilista brasileiro Pedro Lourenço, lançou sua primeira coleção desfilada para o inverno daquele ano inspirada em obras de Oscar (1907-2012), especialmente em um dos marcos de sua arquitetura, os brises. Logo após o seu desfile o estilista disse que "Quando você sonha muito com alguma coisa, acaba virando realidade". Talvez tenha acontecido isso com ele. Sobre sua coleção, o estilista explica que foi, realmente, inspirada na obra de Oscar Niemeyer. "Quero falar do Brasil, mas de coisas boas, e não daquela visão colonizada que muitos têm do nosso país". Pedro inovou com volumes tridimensionais feitos de plástico e/ou couro endurecido. Nas releituras ao usar as tiras horizontais promoveu um toque militar. Também remeteu aos brises homenageando a obra de Niemeyer. A excelência do seu trabalho foi traduzida na precisão dos cortes: linhas puras e formas simples. A coleção com vestidos nas cores branca, bege, nude e marrom imprimiram uma abordagem autoral, com um toque final futurista que diz muito do estilista. Ao final do desfile, Lourenço disse que acredita que suas "referências ficaram mais abstratas, a partir dali". 
Figs 19, 20 e 21. Residencial Niemeyer (1955), Belo Horizonte (MG) e o Edifício Copan (1966), São Paulo Fonte: Chaves, 2017
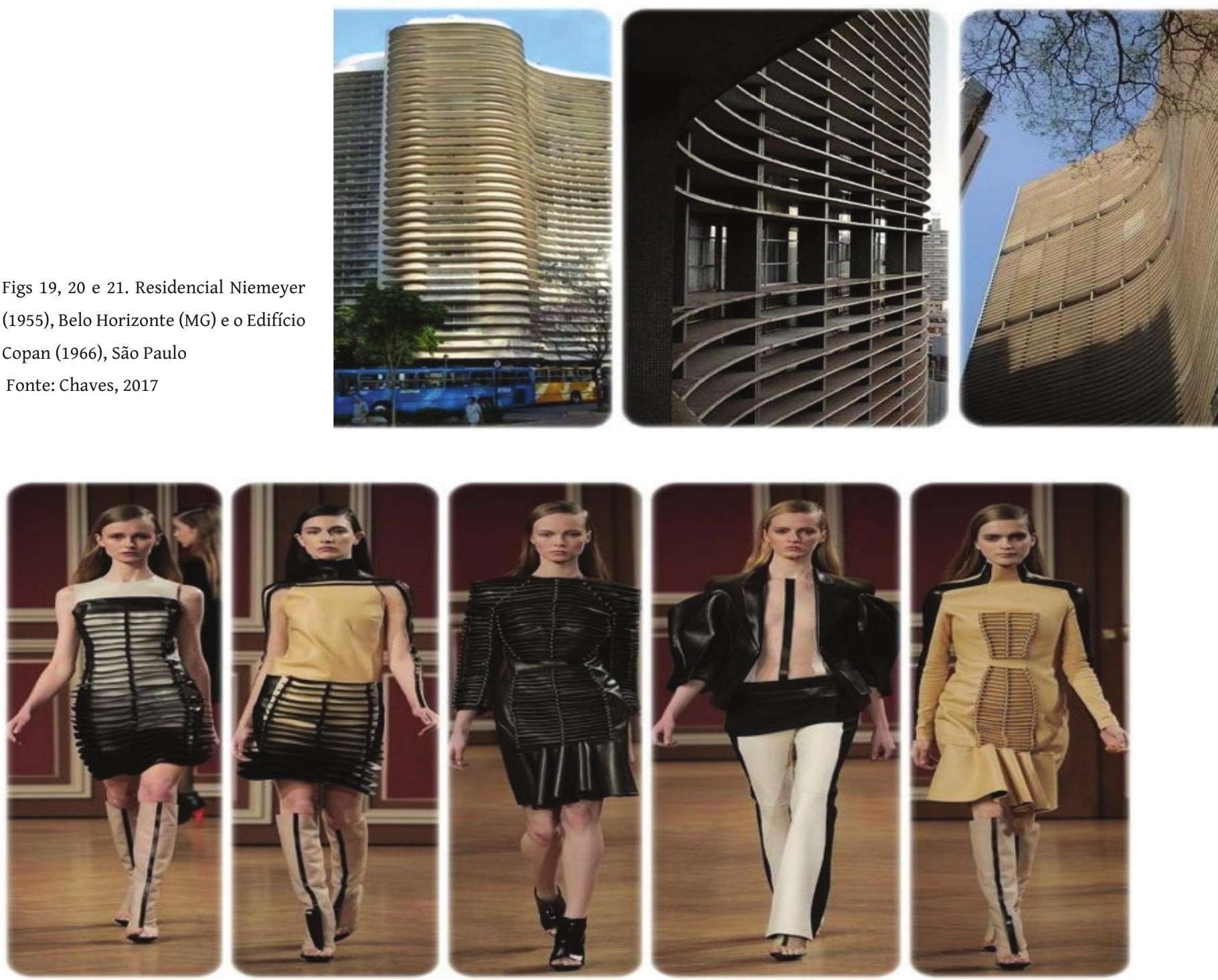

Figs 22, 23, 24, 25 e 26. Coleção Inverno/2010 de Pedro Lourenço inspirada nas obras de Niemeyer Fonte: Chaves, 2017

Figs 27 e 28. Semana da Moda de Paris - 2010. Desfile de Pedro Lourenço inspirada nas obras de Niemeyer Fonte: Chaves, 2017
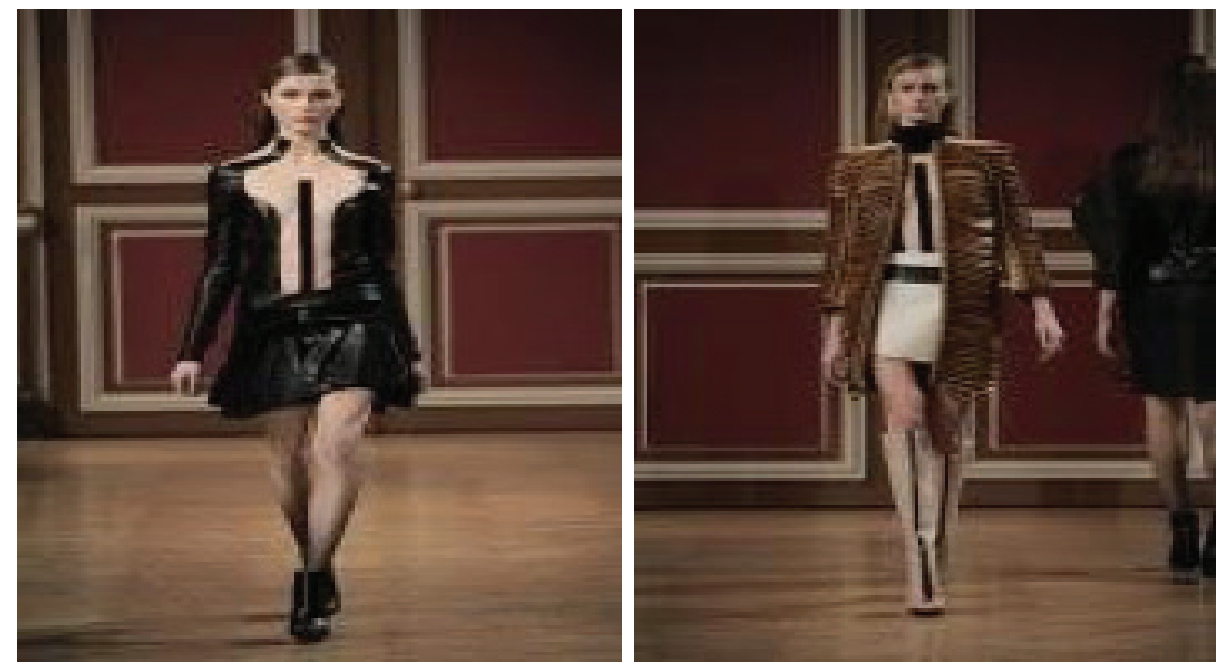
Sendo o arquiteto brasileiro de maior projeção internacional, Niemeyer cria as formas mais originais que o mundo da arquitetura tem reverenciado e é também influência para criadores do mundo da moda também no exterior. "O paralelo entre Niemeyer e a moda vem através do corpo", informa o arquiteto Carlos Albuquerque em sua tese de doutorado "A Corporificação na Obra de Niemeyer". Ele defende que o que os estilistas veem na arquitetura de Niemeyer é a presença do corpo feminino. Comentando que:

\footnotetext{
Ao observar a coleção de verão da Balenciaga, vemos que a linha é muito acentuada, transformando-se em volume e estrutura. As linhas das vigas da catedral de Brasília podem ser lidas como a cintura de um corpo feminino... Balenciaga integra suas roupas ao corpo da mulher; Niemeyer se inspira nas curvas femininas para sua arquitetura. Os dois têm em comum um olhar para a vida e para o feminino. Resultam daí desenhos que bebem na mesma fonte: a mulher (CHAVES, 2017).
}

Já para o arquiteto Arthur Casas, "Balenciaga se inspirou na estética curvilínea e orgânica da obra do arquiteto brasileiro Oscar Niemeyer para criar uma de suas coleções", a de 2004.

Figs 29 e 30. Croqui do Parque Ibirapuera - SP, Projeto de Niemeyer (1954) e Coleção Belenciaga - Verão/2004 Fonte: Chaves, 2017

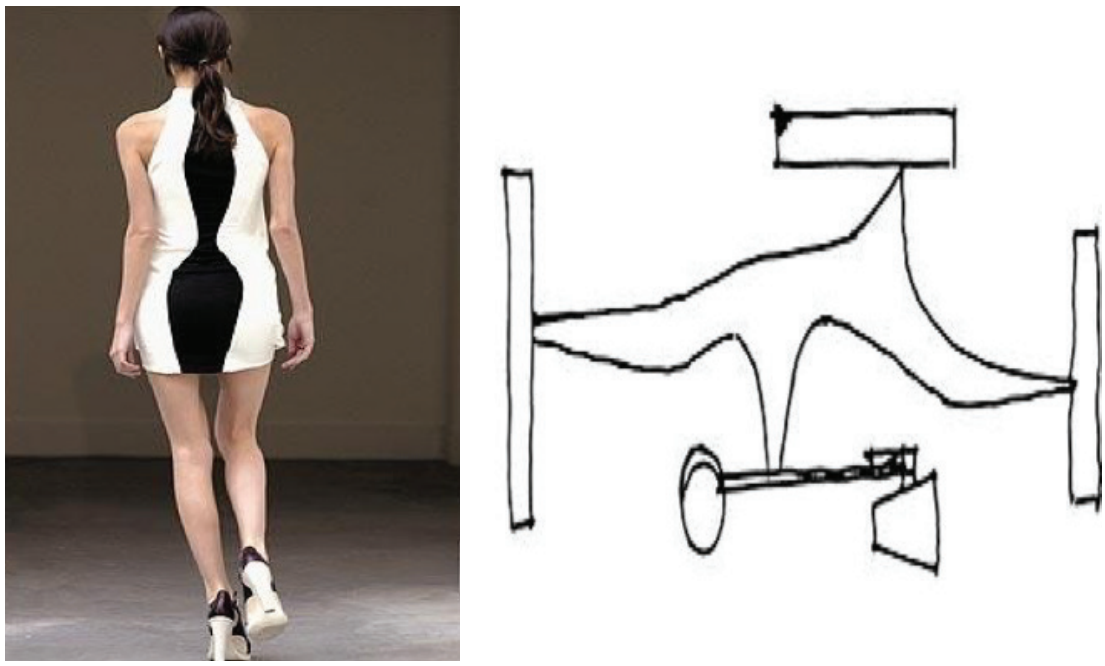

Algumas pessoas dizem que Niemeyer ao projetar a Catedral de Brasília fez a releitura da coroa de Cristo, portanto os "Espinhos de Cristo na Paixão". Outros acreditam que são duas mãos estendidas com os dedos abertos em súplica e outros tantos ainda afirmam que naquele projeto Niemayer inspirou-se num corpo de mulher. Assim, nas primeiras edições do Capital Fashion Week, a estilista Rejane Cadore em uma de suas coleções, inspirou-se na arquitetura de Niemeyer, especialmente naquele projeto tão discutido, a Catedral de Brasília, como mostram as Figuras 31 e 32. 


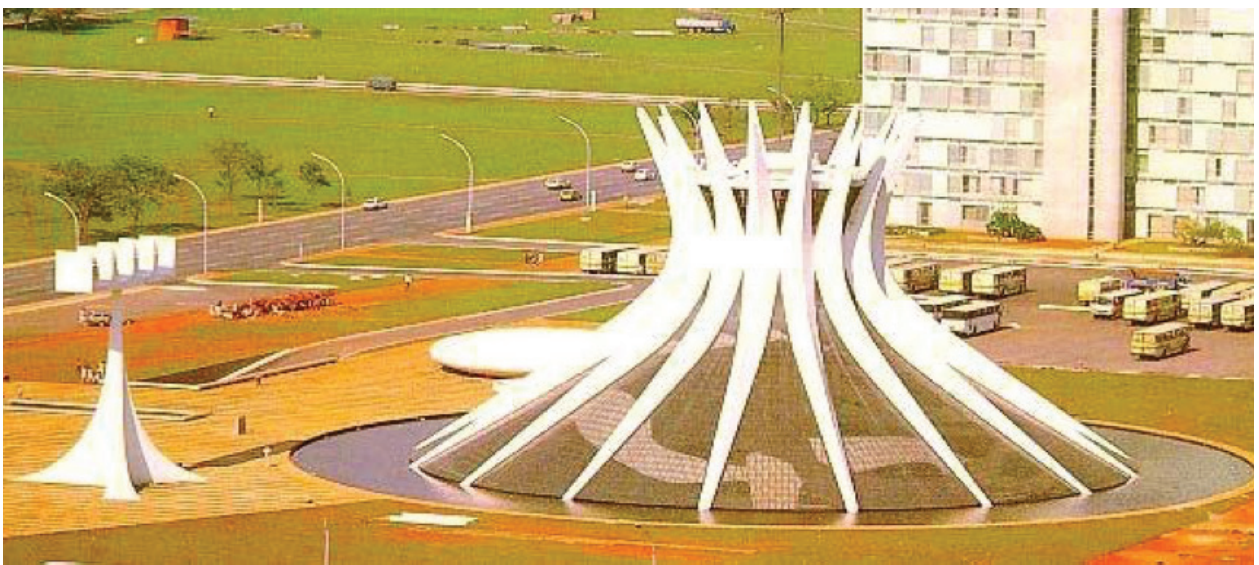

Fig 31. Catedral Metropolitana Nossa Senhora Aparecida, mais conhecida como Catedral de Brasília - Brasília DF, Projeto de Oscar Niemeyer (1954) Fonte: Chaves, 2017
Fig 32. Modelo da estilista Rejane Cadore inspirado na Catedral Metropolitana Nossa Senhora Aparecida, mais conhecida como Catedral de Brasília - Brasília - DF, Projeto de Niemeyer, 1954 Fonte: Chaves, 2017

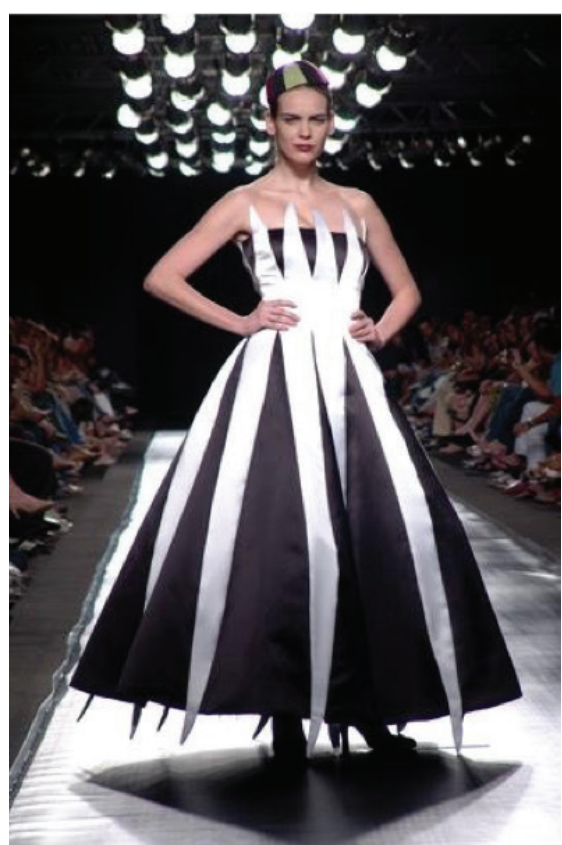

Outro arquiteto brasileiro com inúmeras obras reconhecidas, também mestre das curvas e da organicidade moderna do século 20 é Ruy Ohtake (1938-). Ohtake se inspira e é inspirador para estilistas, como é o caso de Glória Coelho, que em sua coleção de Verão/2010, desfilada na ocasião do São Paulo Fashion Week, abraçou as ondas, os cheios e vazios, e a sinuosidade vista em vários projetos do arquiteto, trazendo-os para a passarela. É na moda que vemos a força e imponência de edifícios ganhar vida e dar forma ao corpo. É na arquitetura que vemos o corpo influenciando a forma destes grandes - um se apoiando no outro.
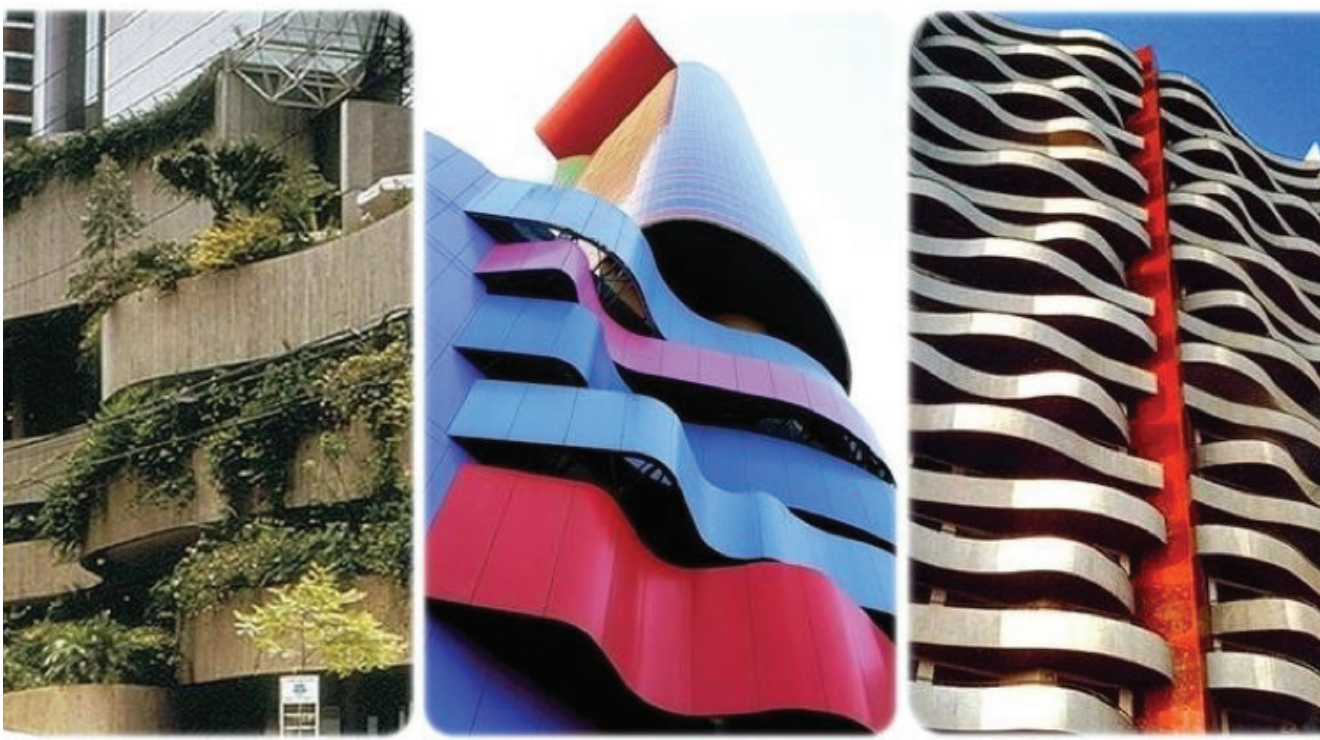

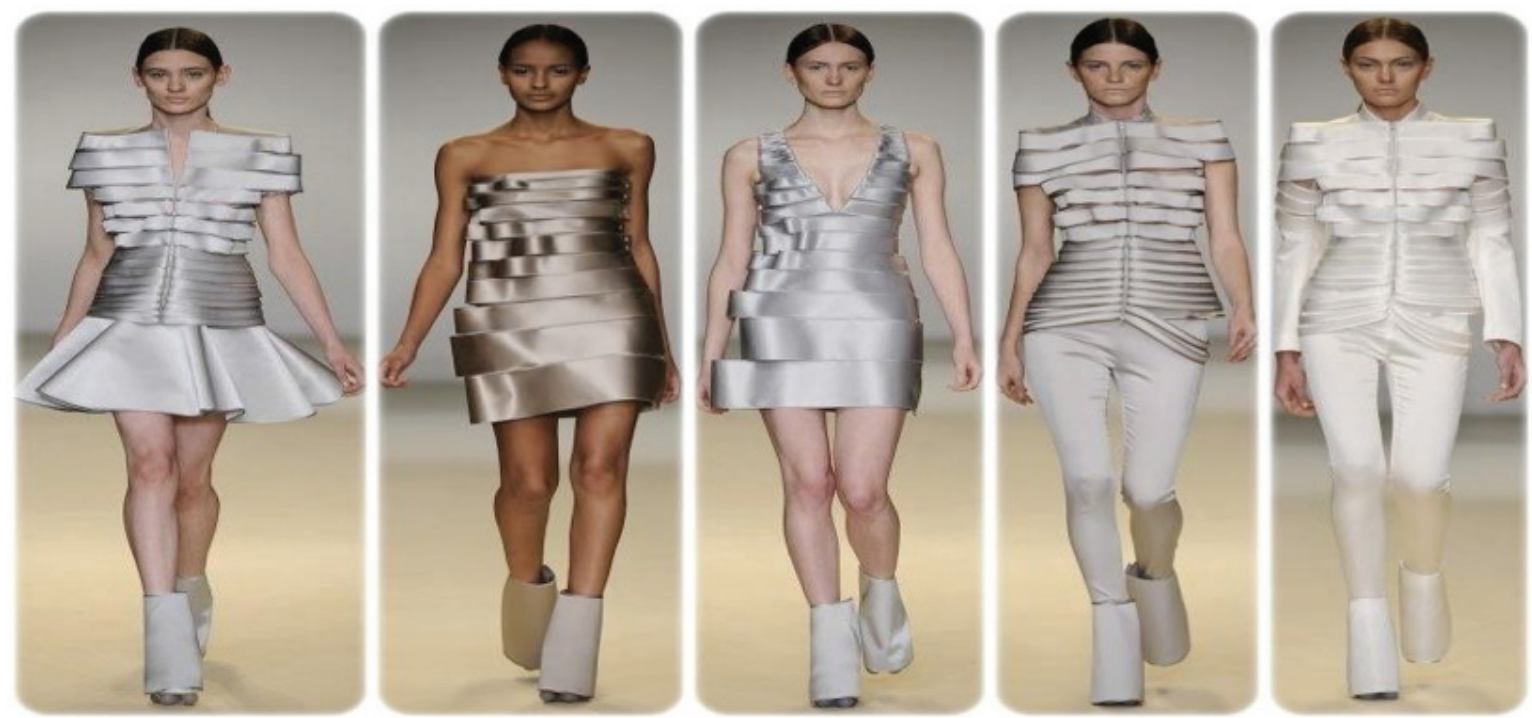

Figs 36, 37, 38, 39 e 40. Coleção de verão 2010 de Glória Coelho inspirada nas obras de Ruy Ohtake Fonte: Chaves, 2017

Resumindo, o arquiteto Isay Weinfeld (1952-) diz que "fazer arquitetura é colocar artes plásticas, cinema, culinária, moda, dança e teatro embaixo de um mesmo telhado". E eu concluo que, moda é colocar artes plásticas, cinema, culinária, arquitetura, dança e teatro costurados em um mesmo corpo.

Miguel Gigante e a arquitetura, montanhas e ruínas de Portugal

Foi em março de 2016, que nas várias conversas/entrevistas feitas com o designer e estilista Miguel Gigante, fiquei sabendo que em outubro do ano de 1971, nascia em Covilhã (Portugal), Carlos Miguel Cerdeira Gigante. Filho de um casal ligado à moda e costura, pois os mesmos possuíram uma fábrica de confecção que produzia peças de vestuário. Miguel é dono de uma persistência como poucos. Acredita no que faz e no que ainda poderá fazer, e também é bastante consciente do que terá que enfrentar.

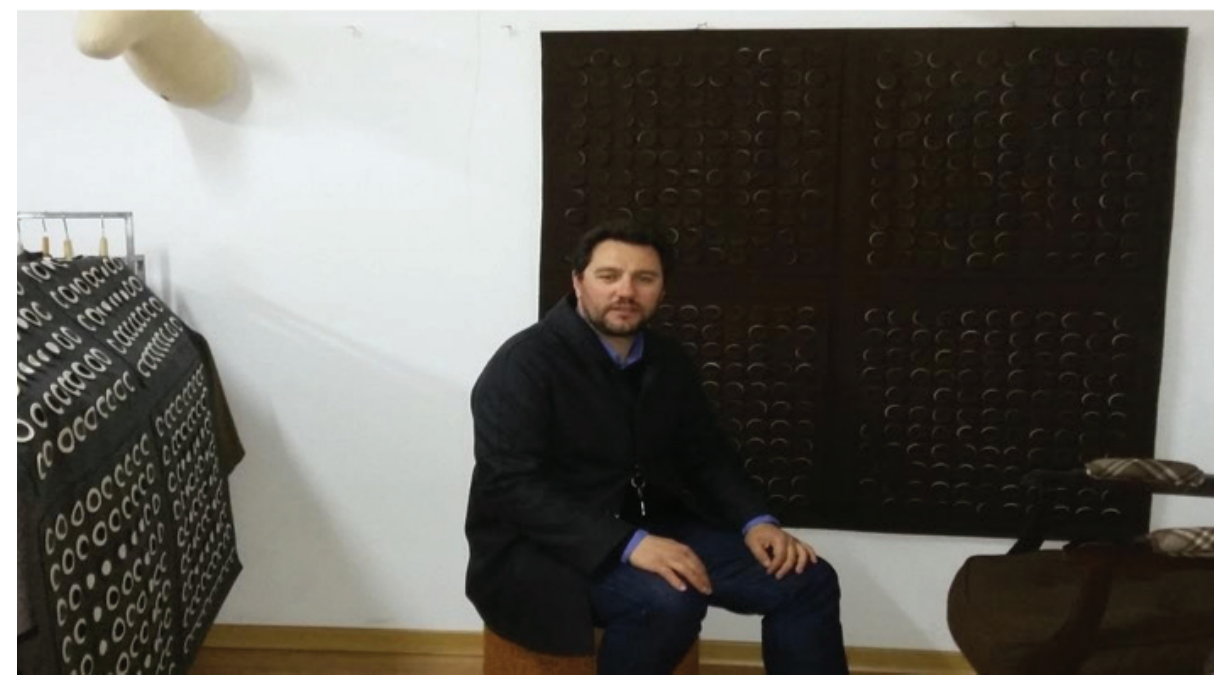

DATJournal v. 5 n.2 2020

Fig 41. O estilista Miguel Gigante no seu Atelier de Burel, 2016

Fonte: Chaves, 2017 
Antes de trabalhar principalmente com a lã, Miguel lembra que trabalhou na indústria têxtil, além de ter ateliê próprio onde aceitava trabalhos particulares, "por medida das pessoas, fazendo desde uma simples saia a vestidos de noivas, fazíamos de tudo no ateliê, e sempre em parceria com a indústria", diz Miguel.

Eu acompanhava o cliente desde a escolha do tecido, gabinete de modelagem, corte, costura até o produto acabado. Era essa a minha relação com a indústria. Só há sete anos iniciei o processo, que era um sonho trabalhar o "collant". Eu gosto mais de trabalhar com o tecido pesado, para o inverno, uma constante por aqui, entretanto também trabalho com o tecido fino, mas é uma coisa forçada, exige um esforço maior de minha parte (CHAVES, 2017).

Miguel é Designer de Moda e antes de começar o curso ele já possuía uma formação técnica. Já trabalhou com modelagem, controle de qualidade, etc., uma vez que seus pais possuíram uma confecção por muitos anos. Sua mãe, falecida há pouco mais de um ano, entre outras qualidades/atividades costurava, bordava, fazia crochê, tricô. Mãe e filho eram desde o início parceiros inseparáveis. Com ela, Miguel foi iniciado na sua vida artística, de costureiro-estilista-designer. Ele comenta que:

Fui criado dentro da fábrica dos meus pais, no meio das costureiras, das máquinas, dos chefes, estilistas, tendo acesso desde muito novo a todo esse universo e todas as informações a respeito do fazer moda. Tive a sorte de ter a mãe que tive. Ela fazia muitas coisas dentro da fábrica e tudo isso que ela sabia eu aprendi com ela, ela me ensinou (CHAVES, 2017).
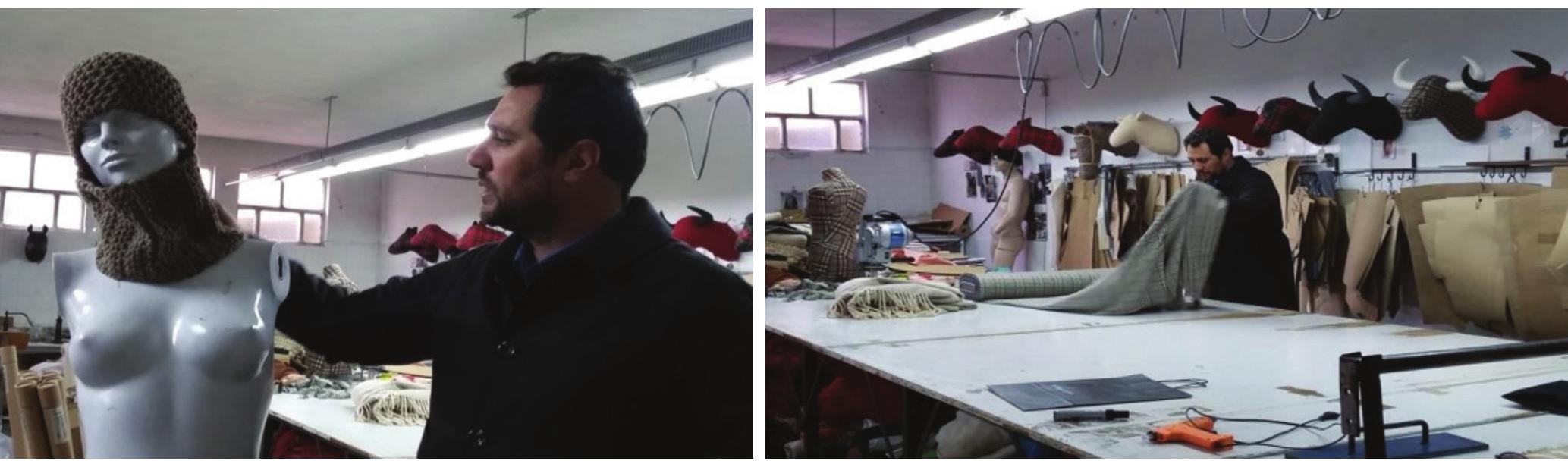

Figs 42 e 43. O estilista Miguel Gigante no seu Atelier de Burel, 2016

Fonte: Chaves, 2017 
Tive a sorte também de descobrir desde muito cedo o que gostava de fazer e nunca mais interrompi um processo evolutivo e normal. 0 trabalho que faço hoje é muito vinculado, muito inspirado ao território, que é a zona onde vivo. Serras, montanhas e todas as atividades que estão ligadas diretamente a ovelha, a pastorícia, da escolha da lã à sua produção. E todo esse processo é pelo fato de viver aqui. Minha cidade nos anos 20, 30, 40, 50 já foi uma grande potência em termos de indústria nos sítios de lã (CHAVES, 2017).

Toda a influência que o rodeia, o acompanha sempre - da estética, da arquitetura, do patrimônio - ele mostra e demonstra através da sua criação com a matéria prima que é a lã.

Tive contato com uma série de pessoas que trabalharam anos na indústria, e com elas assimilei as informações dos vários processos. Não fiz mais nada do que aproveitar tudo aquilo, todas aquelas informações e juntar, compilar num processo onde busco na minha memória e nas coisas do passado, das minhas raízes, o que resulta com aquilo que deve ser um produto contemporâneo, onde o apelo é vestir uma mulher moderna para haver a troca comercial em um projeto de sustentabilidade. Basicamente o meu início foi por aí (CHAVES, 2017).

Miguel possui um ateliê com uma área em torno de 300 metros quadrados e com um maquinário necessário às atividades ali desenvolvidas.
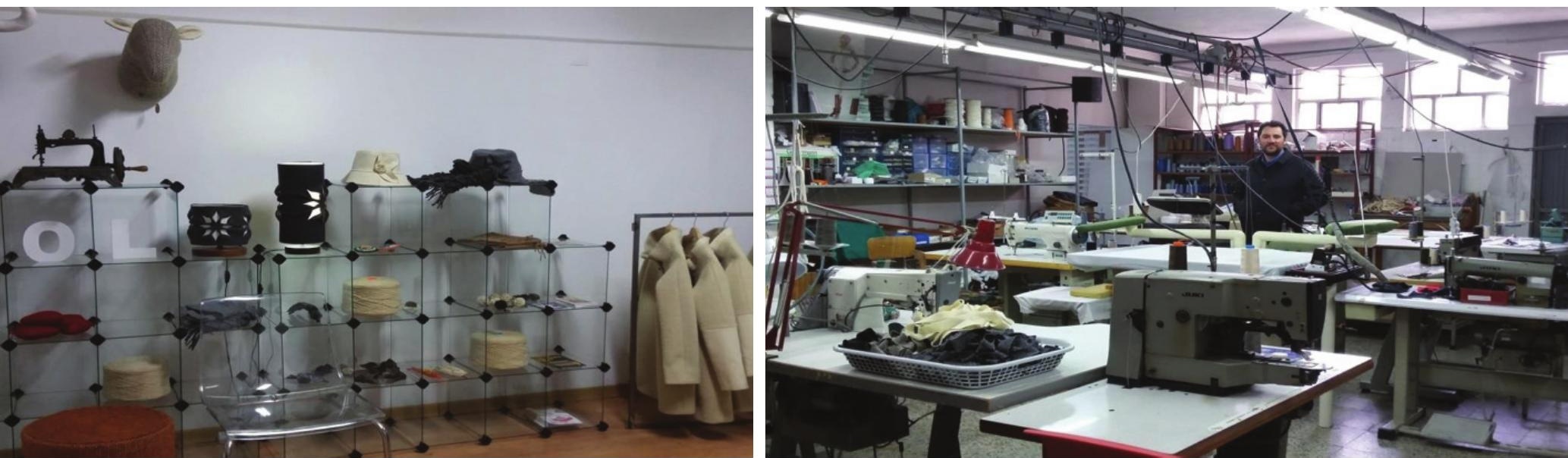

Figs 44 e 45. Ateliê de Burel do estilista Miguel Gigante, 2016

Fonte: Chaves, 2017 
Aqui no ateliê trabalham duas costureiras permanentes e outras dependendo do movimento e estação do ano. Terceirizo o trabalho em tricô à mão e no processo do feitio do tecido, no tear, da escolha da lã, do fio. No meu ateliê não há teares, pois é um atelier de acabamento, de produto acabado. E assim, fico muito de um lado para outro, dos sítios onde se encontram os teares, a escolha do corte e vai para a ultimação, para fazer o processo de acabamento, controlando ao máximo e de muito perto, para obter um produto o mais original, o mais autêntico possível. Meu produto, meu trabalho final é $100 \%$ artesanal (CHAVES, 2017).

Fig 46. Ateliê de Burel do estilista Miguel Gigante, 2016

Fonte: Chaves, 2017

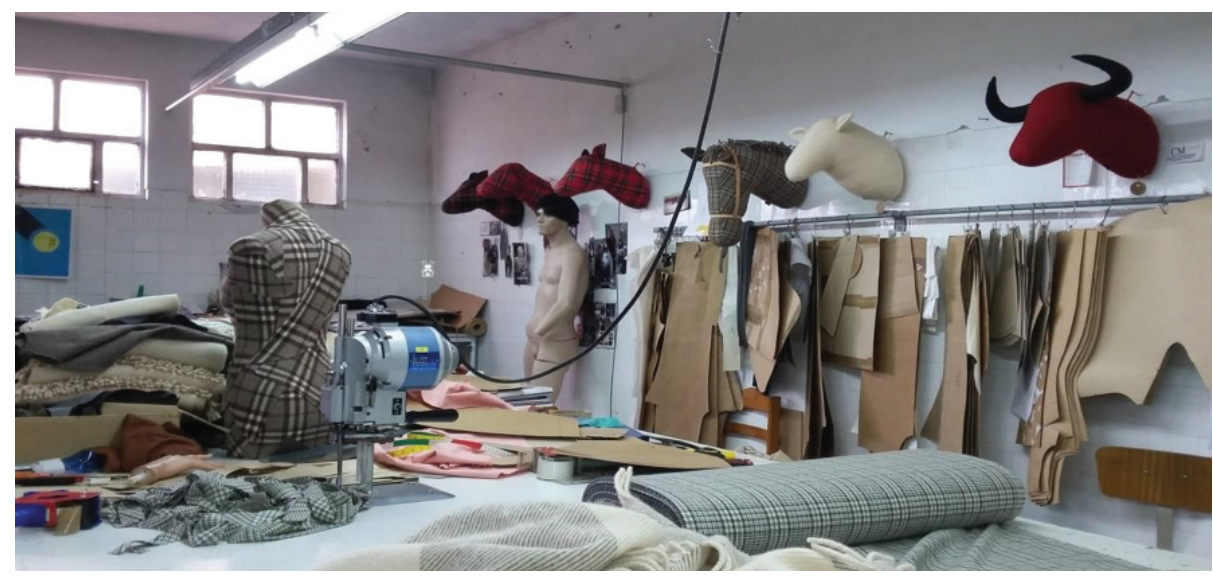

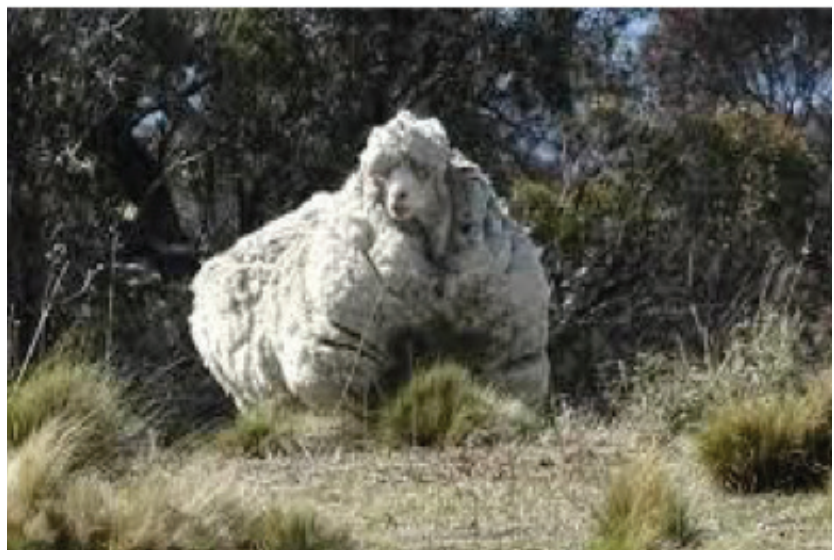

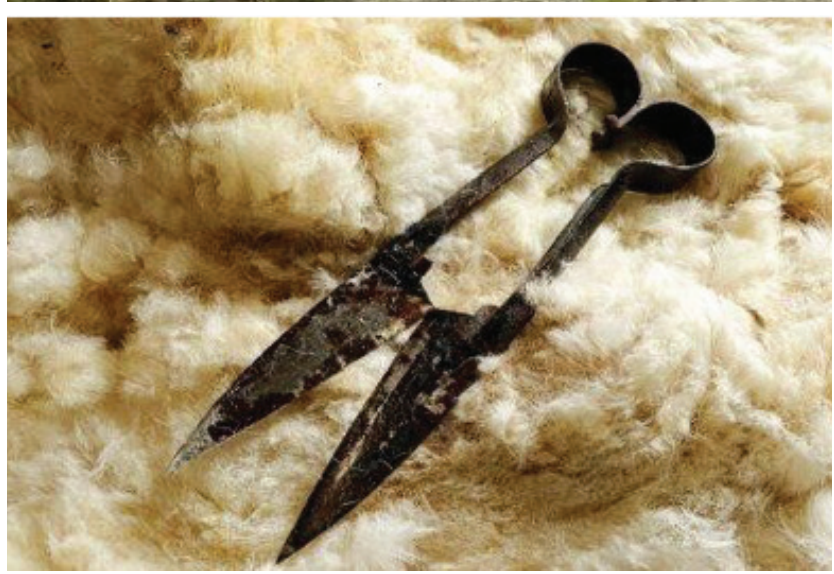

DATJournal v. 5 n.2 2020
Nos meus produtos também uso a malha e tricô, além de alguns tecidos feitos pela indústria, mas são tecidos que se assemelham mais a um produto com um espírito menos industrial, tecidos mais complexos na sua construção de perfeita qualidade, conforme o meu critério. São tecidos que, do meu ponto de vista, mais difíceis de massificar por suas características próprias de acabamento, do preço. $\mathrm{Na}$ realidade, gosto daquilo que a indústria não quer. É isso que vou buscar. É um material menos comercial, menos amado pelo público consumidor que eu o transformo e ele fica, de uma maneira geral, muito apreciado, no final. Sendo a lã a matéria prima para desenvolver minha produção (CHAVES, 2017). 

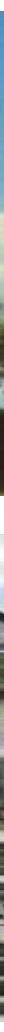

Figs 49, 50, 51, 52, 53 e 54. Patrimônio Arquitetônico que influencia o estilista Miguel Gigante nas suas coleções, 2016 | Fonte: Chaves, 2017

Quando inicio a criação no ateliê de Burel, minha fonte primeira de inspiração e de influência é o que me rodeia na região, no território. Inspiro-me na arquitetura - principalmente das igrejas e ruínas existentes nas redondezas de Covilhã -, nas serras, nas montanhas. Sei que essa influência transparece em todas as minhas coleções. Eu utilizo poucas cores na minha produção e estas são devido à cor da lã que é o bege, o branco, o verde, os crus com exceção do cinzento. Por causa das estruturas dos tecidos, eu bebo nas minhas criações, das influências que têm os padrões das aldeias histórias, o Patrimônio, os castelos medievais, as igrejas, histórias do povo, suas lendas, pois cada aldeia possui sua lenda! (CHAVES, 2017).

Miguel fala que "os italianos respiram o belo, o gosto, o primor". Ele reconhece que seu trabalho tem muita influência de tudo o que se respira na Itália, devido à época em que estudou ali. A história da Itália, o patrimônio arquitetônico italiano e a perfeição no acabamento do conjunto artístico ali existente. Tudo lá o inspira! 
Meu método de trabalho para algumas unidades das coleções é assim: compro o tecido e mando franjar. Do tecido franjado faço as peças e muitas vezes mantas com franjas. Gosto de peças com franjas. No passado fiz fardamentos. Gosto de coisas, dos tecidos que o povo acha que não presta, que é "lixo", e eu aproveito porque é material que eu comprei e que vale dinheiro, como já lhe disse.

Meu processo (de criação) começa com e desde os apontamentos, notas, os "crapuc" (croquis), medição, corte, costura, passar do ferro, até o produto acabado, é tanta gente que passa (pelo processo) que a informação vai se "deturpando", vai se modificando. Cada processo há uma margem de erros. Eu faço o molde ao milímetro, um, dois, três milímetros, ponho branduras. Faço a fôrma como se passa a peça. Todo o meu processo de trabalho tem um rigor. Faço todos os "crapuc" no cartão. Risco com o lápis ou com giz de alfaiate. Prefiro o lápis, pois dá menos diferença uma vez que é bem mais fino. Depois coloco o cartão sobre o tecido. Se riscar esse tecido grosso, como este sítio, com o giz de alfaiate, o giz é grosso, então quando eu vou cortar, vai dar muita diferença. Aumento dois, três, quatro, cinco, seis milímetros, que fazem no final grande diferença. Isso são coisas particulares de cada processo. Depois do corte vai para preparação, vem a entretela, e tem que se ter muito cuidado para fixá-la, pois se não tem esse cuidado fica torcido. Eu trabalho com viés, se não for bem feito, não fica como quero. Um fator muito importante em meu trabalho é o passar do ferro na peça. O ferro é fundamental na minha produção. A forma como se abre uma costura, como se passa a peça.

Busco no final uma peça bem simples e bem acabada. Isso é o fundamental - a peça com o acabamento impecável, esse é o diferencial. Meu caminho é a simplicidade aliado ao acabamento por excelência. Sou fascinado por corte e costura e o desafiar na minha produção é ter minhas peças com o acabamento perfeito.

Aprendi muito cedo que eu seria incapaz de ser o que sou sem o curso de designer que fiz na Itália. Todas as peças que saem do meu ateliê passam pelas minhas mãos, nem que seja no corte, todas as peças saídas do meu atelier sou eu quem corta. $\mathrm{E}$ toda peça-piloto que a faz sou eu. Então digo que faço uma peça de cada peça lançada no mercado. 
Com relação à venda das coleções, faço desfiles e exponho em lugares que vêm gente, shoppings, feiras, etc. Eu e um colega que por vezes trabalhamos juntos montamos em cinco minutos um espaço, um stand e temos como fazer isso, pois nos programamos. Temos material que ao longo do tempo fui fazendo estruturas e adaptando umas peças, montando manequins, e conseguimos montar três stands de exposição ao mesmo tempo. Inclusive um desses já foi montado no Brasil (CHAVES, 2017).
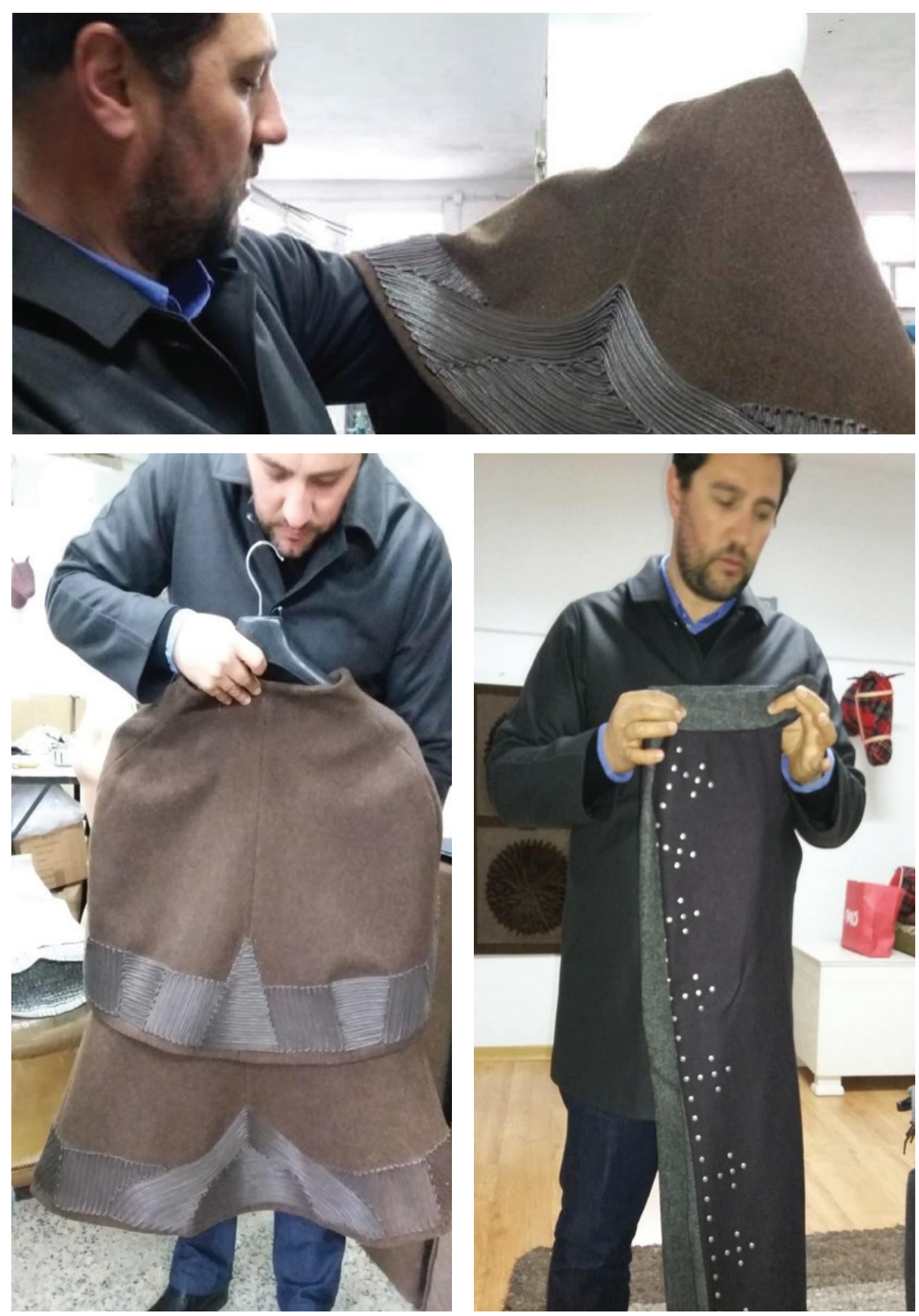

Figs 55, 56 e 57. 0 estilista Miguel Gigante no seu Atelier de Burel, 2016 Fonte: Chaves, 2017 
Fig 58. O estilista Miguel Gigante em um Hotel expondo sua Coleção, 2016 Fonte: Chaves, 2017

Fig 59. Vista da cidade de Covilhã onde reside o estilista Miguel Gigante, 2016 Fonte: Chaves, 2017

Figs 60 e 61. Manequim do Ateliê de Burel. O estilista Miguel Gigante e Liana Chaves usando uma peça do Ateliê de Burel, 2016

Fonte: Chaves, 2017
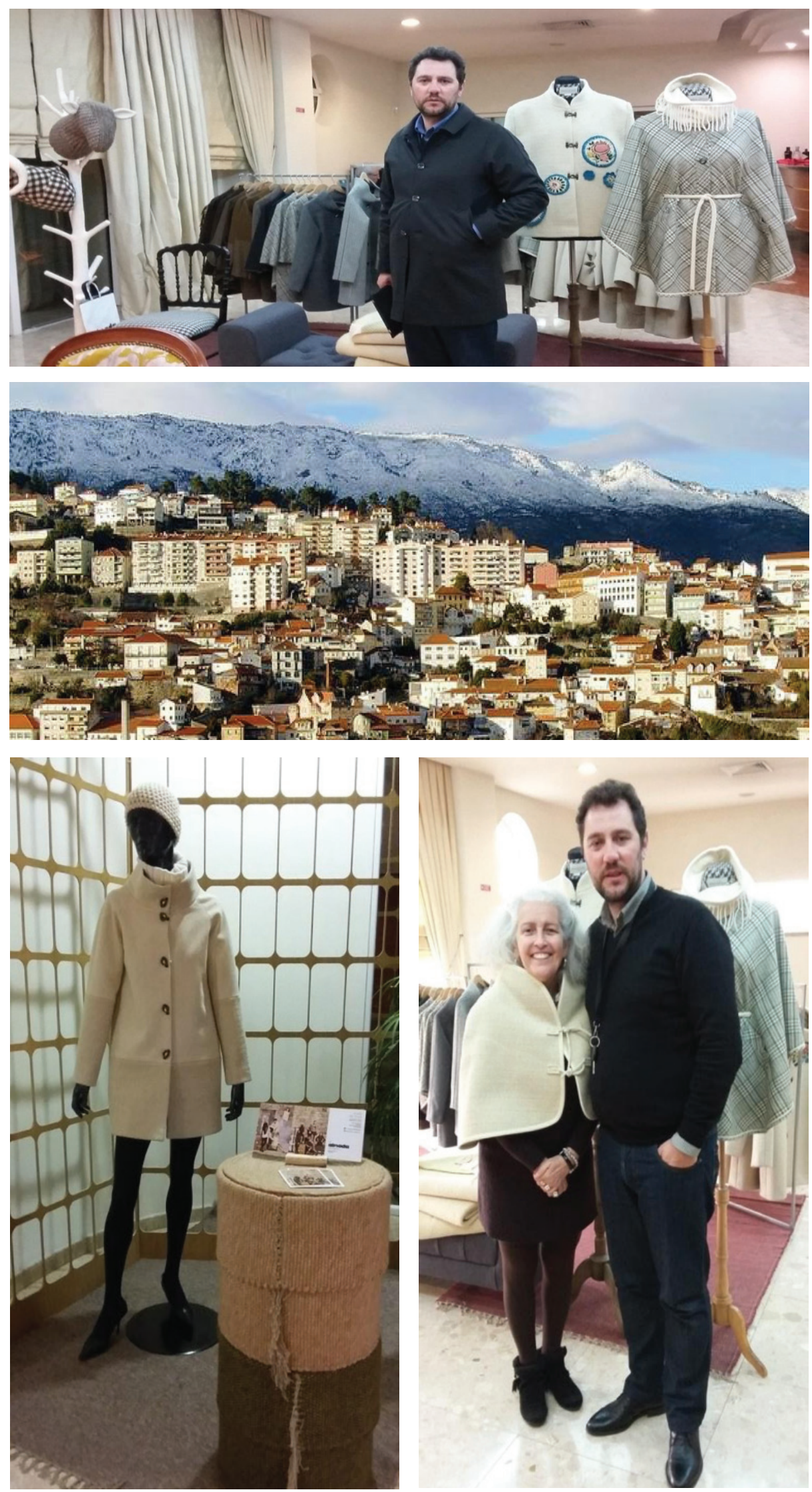
Dessa forma fica muito visível nas Coleções em Burel do estilista Miguel Gigante a influência constante do patrimônio cultural, da arquitetura, principalmente a religiosa, das pedras dos degraus das igrejas da cidade de Covilhã e adjacências, dos pastores, do ambiente militar - nos seus fardamentos, bem como nos dos fardamentos dos religiosos.

\section{Arremates finais}

Apesar de ainda existir uma postura equivocada nas Ciências Humanas e Sociais em considerar a moda como frívola, muitos estudiosos de peso, se esforçam em provar o contrário.

Assim mesmo, ainda hoje a pesquisa neste campo tende a ser revestida de um ar duvidoso, quando não excêntrico, como se o mundo da moda fosse outro mundo e as pessoas ligadas a ele estudassem coisas curiosas e bizarras.

E apesar de existir de fato relação entre arquitetura e moda, estudar e/ou escrever sobre essas duas artes constitui um desafio porque embora haja e se presuma a relação entre ambas, ainda não há uma bibliografia específica.

Entre as duas áreas - moda e arquitetura - existem muitas semelhanças, todavia a principal convergência é que ambas têm como princípio primeiro o de abrigar o indivíduo, pois tanto a casa como a roupa possuem significações psicológicas do caráter de abrigo protetor.

Como as duas artes têm a função de proteção, coloco-me ao lado do arquiteto italiano Francesco Lucchese, que em uma palestra na Expo Revestir em 2010 falou que "a moda e a arquitetura nos protegem, nos dão abrigo e expressam nossa identidade pessoal, política, religiosa e cultural".

Vejo que a influência que existe da Arquitetura na Moda é patente e que a Moda influencia igualmente a Arquitetura.

A moda e a arquitetura, para mim, são artes distintas, muito embora inseparáveis quase que dependentes uma da outra, entretanto nem a moda se encerra no vestir, nem a arquitetura no construir, ambas de uma forma ou de outra se completam.

Assim, tanto a moda como a arquitetura são o efeito colateral das transformações, costumes e comportamentos de uma sociedade. Como nossas vidas, nossas culturas, nossas histórias "as modas e as arquiteturas" são bastante heterogêneas. Dessa forma, a moda tal como a arquitetura vive e convive em harmonia, não existindo a boa e a má, a bonita e a feia, elas existem. 


\section{Referências}

ABREU, Alice Rangel de Paiva. 0 avesso da moda. São Paulo: Hucitec, 1986.

ALBUQUERQUE, Carlos. A Corporificação na Obra de Niemeyer. Universidade de Brandemburgo, Alemanha. Tese de Doutorado.

AU. AU - Edição 133 - abril/2015 - Disponível em: www.au.pini.com.br/arquitetura- urbanismo/133/artigo22714-1.aspx. Acesso em: 13.05.2016.

BARTHES, Roland. Sistemas da moda. São Paulo: Edições 70, 1967. BAUDOT, François. Moda do século. São Paulo: Cosac \& Naify, 1999.

BAUDRILLARD, Jean. A sociedade do consumo. São Paulo: Edições 70, 1981.

BELL, Quentin. Mode et société: essai sur la sociologie du vetement. Paris: Presses Universitaires de France, 1992.

BELTING, Hans. Imagens, Mídia e Corpo: uma nova abordagem a iconologia.

BRAGA, João. História da Moda: uma narrativa. São Paulo: Editora Anhembi Morumbi, $2^{\mathrm{a}}$ edição, 2007.

CALLAN, Georgina O'Hara. Enciclopédia da moda. São Paulo: Companhia das Letras, 2007. CARRANO, Priscila. Morre o ícone da Arquitetura com 104 anos - Oscar Niemeyer e sua influência na moda. In: Estilozzo. Disponível em: http://www.estilozzo.com/index.php/noticias/441-morre-o-icone-da-arquitetura-com-104-anos. Acesso em: 06.12.2012.

CASTILHO, Kathia. Moda e Linguagem. $2^{\mathrm{a}}$ ed. Ver. São Paulo: Editora Anhembi Morumbi, 2009. CASTILHO, Kathia; GALVÃO, Diana. A moda do corpo o corpo da moda. São Paulo: Esfera, 2002. CHAVES, Liana M. A Influência da Arquitetura na Moda Brasileira e Portuguesa. Relatório de pesquisa de Pós Doutorado. Departamento de Artes Visuais. Centro de Comunicações, Turismo e Artes - Universidade Federal da Paraíba (UFPB), João Pessoa/PB. Supervisora: Prof. Dra. Ana Mae Tavares Bastos Barbosa. Departamento de Artes Plásticas. Escola de Comunicações e Artes (ECA) - Universidade de São Paulo (USP), São Paulo/SP, 2017.

CHAVES, Liana. Moda e costura: "a casa e o botão" como viés para inclusão social. Dissertação. João Pessoa: Universidade Federal da Paraíba, Centro de Ciências Humanas, Letras e Artes, Programa de Pós-Graduação em Serviço Social, julho de 2007.

CIDREIRA, Renata Pitombo. Os sentidos da moda. São Paulo: Ed. Annablume, 2005.

COSTA, Lúcio. Registro de uma vivência. São Paulo: Empresa das Artes, 1995.

CRANE, Diana. A moda e seu papel social: classe, gênero e identidade das roupas. São Paulo: SENAC, 2000.

CROCI, Paula e VITALE, Alejandra. (Org.). Los cuerpos dociles: hacia um tratado sobre la moda. Buenos Aires: La marca editora, 2000.

DISITZER, Márcia e VIEIRA, Silvia. A moda como ela é. Rio de Janeiro: Senac, 2006.

DONAKAZA. A Barriga do Estilista. DonaKaza. Disponível em: http://donakaza.blogspot. com.br/2012/01/ barriga-do-estilista-arquitetura-esta.html Acesso em: 13.05.2016.

ECO, Umberto et al. O hábito fala pelo monge. In Psicologia do Vestir. Lisboa, Ed. Assírios \& Alvin, 3ª edição, 1989.

FISCHER-MIRKIN, Toby. 0 código do vestir. Rio de Janeiro: Rocco, 2001.

FLÜGEL, J.C. A psicologia das roupas. São Paulo: Mestre Jou, 1966.

FROMENT, Jean-Louis et al. Fashion passion: 100 anos de moda na OCA. São Paulo: Brasil Connects Cultura, 2004.

GIRARD, Suzana Moreira. A Moda é um mass media. A Tarde, Salvador: janeiro de 1995. Encarte "Moda, Comunicação e Cultura" da Universidade Aberta do Nordeste. Fascículo II. 
GONTIJO, Silvana. 80 anos de moda no Brasil. Rio de Janeiro: Nova Fronteira, 1987.

KALIL, Glória. Novos tempos, novos códigos. Veja on-line. Disponível em: http://veja. abril.com.br/idade/exclusivo/010904/trecho_sociedade.html, Acesso em: 31/10/2006.

LIMA, Vera. A construção do corpo nas formas da moda. In: CASTILHO, Kathia; GALVÃO, Diana (Org.). A moda do corpo o corpo da moda. São Paulo: Ed. Esfera, 2002. LIPOVETSKY, Gilles. 0 império do efêmero: a moda e o seu destino nas sociedades modernas. São Paulo: Companhia das Letras, 1989.

LIPOVETSKY, Gilles. Os tempos hipermodernos. São Paulo: Barcarolla, 2004.

LUCCHESE, Francesco. Palestra sobre Arquitetura e Moda na feira Revestir 2010. (Trechos). Disponível em: http://www.fashionbubbles.com/historia-da-moda/a-moda-e-arquitetura-nunca-estiveram-tao-proximas/. Acesso em: 30/03/2016.

MAFFESOLI, Michell. $\mathrm{O}$ tempo das tribos: o declínio do individualismo nas sociedades de massa. $2^{a}$ edição. Rio de Janeiro: Forense - Universitária, 1998.

MARHSALL, Sahlins. Cultura e razão prática. Rio de Janeiro: Zahar Editores, 1979.

MCLUHAN, Marshall. Os meios de comunicação como extensões do homem. São Paulo: Cultrix, 1964.

MCLUHAN, Marshall; FIORE, Quentin. Guerra e paz na aldeia global. Rio de Janeiro: Distribuidora Record, 1971.

MELLO, Márcia Maria Couto. A arquitetura, urbanismo e a moda. Disponível em: http:// unuhospedagem.com.br/revista/rbeur/index.php/anais/article/view/3770 Acesso em: 13.05.2016.

OLIVEROS, Ricardo. Blog Fora de Moda - Disponível em: https://forademoda.wordpress. com/category/kenzo-tange/. Acesso em: 13.05.2016.

PAGÊS-DELON, Michèle. Le corps et ses apparences: i'envers du look. Paris: Editions L'Harmattan, 1989.

REBELLO, Yopanan et al. Tecnologia in Revista AU - edição 133 - abril/2005. ROSSI, Aldo. A arquitetura da cidade. São Paulo: Ed. Martins Fontes, 2001.

SIMMEL, Georg. La pariré et autres essais. Paris: Presses Universitaires de France, 1998. VINCENT-RICARD, Françoise. As espirais da moda. Rio de Janeiro: Paz e Terra, 1987. WILSON, Elizabeth. Enfeitada de sonhos: moda e modernidade. Lisboa: 1989. ZANDOMENECO, Ingrid Etges. ARQUITETURA, DESIGNER, INTERIORES. Disponível em: http://arqsc.com.br/site/o-corpo-e-o-lugar-as-relacoes-entre-moda-e-arquitetura/ Acesso em: 13.05.2016. 